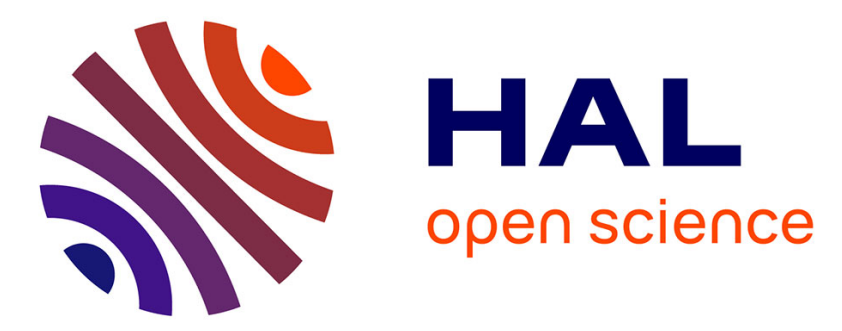

\title{
Interaction of a Model Peptide on Gram Negative and Gram Positive Bacterial Sliding Clamps
}

Christophe André, Isabelle Martiel, Philippe Wolff, Marie Landolfo, Bernard Lorber, Cyrielle Silva da Veiga, Annick Dejaegere, Philippe Dumas, Gilles Guichard, Vincent Olieric, et al.

\section{To cite this version:}

Christophe André, Isabelle Martiel, Philippe Wolff, Marie Landolfo, Bernard Lorber, et al.. Interaction of a Model Peptide on Gram Negative and Gram Positive Bacterial Sliding Clamps. ACS Infectious Diseases, 2019, 5 (6), pp.1022-1034. 10.1021/acsinfecdis.9b00089 . hal-02379658

\section{HAL Id: hal-02379658 https://hal.science/hal-02379658}

Submitted on 25 Nov 2019

HAL is a multi-disciplinary open access archive for the deposit and dissemination of scientific research documents, whether they are published or not. The documents may come from teaching and research institutions in France or abroad, or from public or private research centers.
L'archive ouverte pluridisciplinaire HAL, est destinée au dépôt et à la diffusion de documents scientifiques de niveau recherche, publiés ou non, émanant des établissements d'enseignement et de recherche français ou étrangers, des laboratoires publics ou privés. 


\title{
Interaction of a Model Peptide on Gram Negative and Gram Positive Bacterial Sliding Clamps.
}

\author{
Christophe André ${ }^{\natural}+$, Isabelle Martiel $^{\dagger+}$, Philippe Wolff $^{\S}{ }^{+}$, Marie Landolfo ${ }^{\S}$, Bernard \\ Lorber $^{\S}$, Cyrielle Silva da Veiga ${ }^{\S}$, Annick Dejaegere ${ }^{\mathfrak{f}}$, Philippe Dumas ${ }^{\ddagger}$, Gilles \\ Guichard $^{\natural}$, Vincent Oliéric ${ }^{\ddagger}$, Jérôme Wagner" and Dominique Y. Burnouf ${ }^{\S}$. \\ ${ }^{\S}$ Université de Strasbourg, CNRS, Architecture et Réactivité de l'ARN, UPR 9002, Institut de Biologie \\ Moléculaire et Cellulaire du CNRS, 15 rue René Descartes, F-67000 Strasbourg, France \\ ${ }^{\mathrm{t}}$ Swiss Light Source (SLS), Paul-Scherrer-Institute (PSI), Villigen, Switzerland. \\ ${ }^{x}$ Institut Européen de Chimie et Biologie, Université de Bordeaux-CNRS UMR 5248, CBMN, 2, rue Robert \\ Escarpit, 33607 Pessac, France. \\ ${ }^{\mathfrak{E}}$ Institut de Génétique et de Biologie Moléculaire et Cellulaire (IGBMC), Département de Biologie Structurale et \\ Génomique, 1 rue Laurent Fries, BP10142, 67404 Illkirch, France

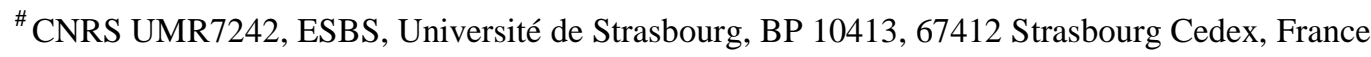 \\ ${ }^{ \pm}$IGBMC, 1 rue Laurent Fries, BP 10142, 67404 Illkirch CEDEX
}

${ }^{+}$: these authors equally contribute to this work.

Keywords: sliding clamp, ITC, kinITC.

SUMMARY.

Bacterial sliding clamps control the access of DNA polymerases to the replication fork and are appealing molecular targets for antibacterial drugs development. To this end, it is critical to decipher the polymerase-clamp binding mode across various bacterial species. We showed previously that synthetic peptides targeting the clamp binding pocket of Gram- bacteria poorly interact with that of Gram+ homologous proteins. Here we analyzed the interaction of a reference peptide with several E. coli and B. subtilis clamp variants. For both Gram- and Gram+ pockets, the peptide binds through an induced-fit process but the complex stability 
varies according to a pocket specific network of interactions. Thermodynamic and molecular dynamics analyses identify a strategic position in the pocket where a mobile residue is necessary for an efficient peptide interaction. A residue at another position modulates the folding dynamics of the pocket upon ligand binding in E. coli, while in B. subtilis, this residue is essential for polymerase activity and might thus be a Gram+ specific molecular marker. 


\section{INTRODUCTION.}

Bacterial resistance to antibiotics is a major threat for human health. According to several official reports, a return to the pre-antibiotic era during the 21 st century is a realistic possibility ${ }^{1}$. In order to tackle this challenge, one strategy aims at identifying new bacterial molecular targets and at developing efficient molecules that will block their physiological functions. The bacterial processivity factor, also referred to as the sliding clamp (SC), has been previously identified as a potential drugable new target 23456 . The ultimate proof of concept was recently brought by the natural cyclic peptides griselimycins that bind to Mycobacterium tuberculosis sliding clamp $\left({ }^{M t} \mathrm{SC}\right)$ and display good in vivo anti-bacterial activity in animal models ${ }^{7}$. However, the molecular mechanisms that govern the SC/ligand interaction are not well understood ${ }^{4589}$.

In bacteria, SC is a homodimer that encircles and slides along double stranded DNA ${ }^{10}$. It binds the replicative DNA polymerase, thus conferring a high processivity to the resulting holoenzyme ${ }^{11}{ }^{12}$. It also serves as a molecular hub on which all the other DNA polymerases bind (polI, II , IV and V in E. coli) ${ }^{13}{ }^{14}$ as well as other enzymes involved in DNA metabolism ${ }^{15}$ and this interaction is required for these proteins to fulfill their functions ${ }^{13}$. Remarkably, in all cases, SC-protein interaction is mediated by a short peptide segment which encompasses the consensus sequence (QL[S/D]LF) ${ }^{16}$. This peptide portion binds SC within a hydrophobic pocket located between domains II and III of SC ${ }^{173}$ and formed by two sub-sites joined by a shallow groove: sub-site 1, also referred to as the leucine-rich pocket, interacts with the C-terminal part of the peptide, whereas sub-site 2 binds the highly conserved Q residue (SI.1).

We have previously observed that short synthetic peptides designed to bind to Escherichia coli SC $\left({ }^{E c} \mathrm{SC}\right)$ with an increased affinity also interact efficiently with SC from other Gram- bacteria such as Pseudomonas aeruginosa ${ }^{5}$. However, they show a lower interaction with ${ }^{M t} \mathrm{SC}$ and fail to interact efficiently with SC from other Gram+ strains such as Staphylococcus aureus and Bacillus subtilis $\left({ }^{B s} \mathrm{SC}\right)$, suggesting that peptide binding on SC occurs through a different process in Gram+ and Gram- bacteria ${ }^{18}$.

A careful analysis of the peptide binding process on ${ }^{E c} \mathrm{SC}$ revealed that a fully efficient binding pocket folds upon peptide binding ${ }^{3} 519$. Notably, two residues, $\mathrm{S}_{346}$ and $\mathrm{M}_{362}$, seem to play a strategic role in the interaction process as, upon peptide interaction, their side chains 
undergo a large concerted movement that allow the opening of a groove in which the linear peptide can lie ${ }^{5}$ (SI.1). Interestingly enough, these two residues are conserved in Gramstrains but not in Gram+ bacteria, where they are essentially replaced by proline and leucine/threonine, respectively. Noteworthy, in ${ }^{M t} \mathrm{SC}$ only the residue corresponding to ${ }^{E c} \mathrm{SC}$ $\mathrm{S}_{346}$ is changed into proline, whereas the methionine residue $\left({ }^{M t} \mathrm{SC}_{396}\right)$ is conserved. Thus, as far as these two residues are concerned, ${ }^{M t} \mathrm{SC}\left(\mathrm{P}_{362}, \mathrm{M}_{396}\right)$ stands as an intermediate between

${ }^{E c} \mathrm{SC}\left(\mathrm{S}_{346}, \mathrm{M}_{362}\right)$ and ${ }^{B s} \mathrm{SC}\left(\mathrm{P}_{357}, \mathrm{~L}_{373}\right)$ (Table 1). These observations, in correlation with peptide binding analyses ${ }^{18}$, suggest that the mode of peptide interaction might be linked to the gating function of these two residues.

In this work, we evaluate the respective contribution of residues ${ }^{E c} \mathrm{SC} \mathrm{S}_{346}$ and ${ }^{E c} \mathrm{SC}$ $\mathrm{M}_{362}$ and their corresponding residues in ${ }^{M t} \mathrm{SC}$ and ${ }^{B s} \mathrm{SC}$, to peptide binding. For each $\mathrm{SC}$, every residue was mutated $(\mathrm{M} \rightarrow \mathrm{L}, \mathrm{S} \rightarrow \mathrm{P}, \mathrm{L} \rightarrow \mathrm{M}$ and $\mathrm{P} \rightarrow \mathrm{S})$, leading to a series of single and double mutants (Table 1). The interaction of peptide $\mathbf{P}_{7}$ (AcQXDLF, $\mathrm{X}=$ cyclohexylalanyl, Cha) (SI.2) ${ }^{5}$ with each of these SCs was analyzed by ITC, X-Ray crystallography, molecular dynamics and in vitro replication assays. Our results reveal the prominent role of these residues for the peptide interaction with Gram- and Gram+ SC, and will have strong implications for the design of strain-specific anti-replicative molecules.

\section{MATERIAL AND METHODS.}

\section{Construction of mutant SC, expression and purification of processivity factors.}

Plasmids pET15b containing the dnaN genes from E. coli, M. tuberculosis or B. subtilis 18 were site specifically mutagenized using the Quikchange ${ }^{\circledR}$ procedure (Stratagene). Oligonucleotides were from IDT. Selected recombinant plasmids were sequenced (GATC, Kontanz, Ge) and transformed in BL21 (DE3) pLys E. coli strains. For expression of dnaN proteins, cells were grown in $\mathrm{LB}$ at $37^{\circ} \mathrm{C}$ to $\mathrm{OD} 0.5$, then induced by IPTG $(0.1 \mathrm{mM})$ at $28^{\circ} \mathrm{C}$ overnight. dnaN proteins fractions were first enriched on a Ni-NTA column, eluted with an histidine step (300 $\mathrm{mM}$ ) and further purified on a Source Q column in buffer containing 20 $\mathrm{mM}$ Tris $\mathrm{HCl} \mathrm{pH} 7.5,0.5 \mathrm{mM}$ EDTA and $10 \%(\mathrm{v} / \mathrm{v})$ glycerol, using a gradient from 0 to 0.5 $\mathrm{M} \mathrm{NaCl}$. After a final ultracentrifugation $\left(45 \mathrm{~K}, 1 \mathrm{~h}, 20^{\circ} \mathrm{C}\right)$, soluble proteins were concentrated on a Centricon $30 \mathrm{~K}$ (Millipore) in the same buffer and stored at $4^{\circ} \mathrm{C}$ in $2 \mathrm{M}$ ammonium sulfate. Buffer exchange was performed on Centrikon $10 \mathrm{~K}$ at $4^{\circ} \mathrm{C}$ before use and protein quality was assessed by DLS analysis (SI.3). 


\section{Peptide synthesis.}

Procedure for the synthesis of peptide $\mathbf{P}_{7}$ has been described elsewhere ${ }^{5}$. The chemical formula is shown in supporting information (SI.2)

\section{Isothermal Titration Calorimetry.}

ITC was performed using an iTC $_{200}$ (Microcal Malvern Panalytical) or a PEAQ-ITC instrument (Microcal Malvern Panalytical). Peptides (300 or $600 \mu \mathrm{M})$ were titrated at different temperatures $\left(15,25\right.$ and $34^{\circ} \mathrm{C}$ ) by sequential injections (usually $2 \mu \mathrm{l}$ each) into a $\mathrm{SC}$ solution $(30$ or $60 \mu \mathrm{M})$. Data were corrected for heat of injection by subtracting the signal of the titration of peptides into protein-free buffer solution (Hepes $10 \mathrm{mM} \mathrm{pH} \mathrm{7.4,} \mathrm{NaCl} 0.15 \mathrm{M}$, EDTA $3 \mathrm{mM}$ ) (SI.4). Each titration was performed at least twice. Analyses of experimental data were performed following a classical treatment with the AFFINImeter software (https://www.affinimeter.com; S4S, Santiago de Compostela, Spain). Both types of analyses yield similar data (data not shown). Non classical methods were also used. First a global thermodynamic treatment (GTT, see below) was performed. In addition, kinetic information was obtained in some cases with kinITC ${ }^{2032}$ as implemented in the software AFFINImeter. A comparison of GTT and classical treatment analyses is presented in SI.5. All thermodynamic data are provided in SI.6, representative titration curves are presented in SI.7 and all thermodynamic profiles are presented in SI.8.

\section{Global thermodynamic treatment (GTT) of ITC experiments.}

This procedure has been described in ${ }^{20}$. Briefly, the method consists in using a single reduced set of parameters to fit at once all experimental titration curves obtained at different temperature. The free parameters are $\mathrm{K}_{\mathrm{d} 0}$ and $\Delta \mathrm{H}_{0}$, the values of $\mathrm{K}_{\mathrm{d}}$ and $\Delta \mathrm{H}$ at a reference temperature $\mathrm{T}_{0}$ (the mean temperature of all experiments) and $\Delta \mathrm{C}_{\mathrm{p}}=\partial \Delta \mathrm{H} / \partial \mathrm{T}$ governing the evolution of $\Delta \mathrm{H}$ with the temperature. These three parameters alone, have to replace $2 \times \mathrm{N}_{\exp }$ parameters (one $\mathrm{K}_{\mathrm{d}}$ and one $\Delta \mathrm{H}$ for each experiment). This GTT yields theoretical curves describing the evolution of all thermodynamic parameters with the temperature. These curves are shown with the points corresponding to the results from the usual individual treatments: it is important to stress that they do not result from a fit of these points (see Figure 1). A comparison of the data obtained by GTT and classical treatment is presented in SI.5. When the peptide interaction with SC was weak, the deviation between the points from the 
individual treatments and the curve from GTT was large (see Figure 1B and SI.5 B). In these cases, the reported results are from the individual treatments. Of course, the discrepancy just mentioned is a mark of poor quality.

\section{Crystallogenesis, $\mathrm{X}$-ray diffraction, data collection and processing.}

Crystals of ${ }^{E c w t} \mathrm{SC} / \mathbf{P}_{7}$ and ${ }^{E c \mathrm{Mt}} \mathrm{SC} / \mathbf{P}_{7}$ complexes were obtained by screening the crystallization reagent kit PEG/Ion HT from Hampton Research. $200 \mathrm{~nL}$ sitting drops were prepared on plates (Greiner XTL round) by mixing 50 or $100 \mathrm{~nL}$ of preformed $\mathrm{SC} / \mathbf{P}_{7}$ complexes (protein concentration from 6 to $12 \mathrm{mg} / \mathrm{ml}$; protein/peptide ratio: 1.5) with 150 or $100 \mathrm{~nL}$ of crystallization solution, using a Mosquito pipetting station (TTP Labtech). Plates were incubated at $20^{\circ} \mathrm{C}\left({ }^{\mathrm{Ec}} \mathrm{SC}\right)$ or $4{ }^{\circ} \mathrm{C}\left({ }^{\mathrm{Mt}} \mathrm{SC}\right)$. Crystals were obtained in several crystallization conditions and were frozen in liquid ethane. Crystals with the higher resolution were obtained in the following conditions: ${ }^{E c w t} \mathrm{SC} / \mathbf{P}_{7}$ : MES $50 \mathrm{mM} \mathrm{pH} \mathrm{6,} \mathrm{CaCl2} 50 \mathrm{mM}$ PEG400 $30 \%$ (m/v) + PEG/Ion HT kit condition E6 (0.2 M sodium malonate pH 6, PEG $335020 \%$ (m/v)). ${ }^{E c \mathrm{M} 1} \mathrm{SC} / \mathbf{P}_{7}$ : MES $50 \mathrm{mM} \mathrm{pH} \mathrm{6,} \mathrm{CaCl2} \mathrm{50mM,} \mathrm{PEG400} \mathrm{28 \%} \mathrm{(m/v)} \mathrm{+} \mathrm{PEG/Ion} \mathrm{HT} \mathrm{kit}$ condition B3 (0.2 M lithium nitrate, PEG $335020 \%(\mathrm{~m} / \mathrm{v}), \mathrm{pH} 7.1) .{ }^{M t w t} \mathrm{SC} / \mathbf{P}_{7}$ : Acetate de Na $3.2 \mathrm{M}$ pH 6.9, PEG $335018 \%(\mathrm{~m} / \mathrm{v})$ + PEG/Ion HT kit condition A2 (0.2 M potassium fluoride, PEG $335020 \%$ (m/v), pH 7.3). ${ }^{\mathrm{M} t \mathrm{M} 1} \mathrm{SC}_{\mathbf{P}}$ : Acetate de Na $3.2 \mathrm{M} \mathrm{pH} 6.9$, PEG 3350 $18 \%(\mathrm{~m} / \mathrm{v})+$ PEG/Ion HT kit condition B8 (Magnesium formate dihydrate 0.2 M; PEG 3350 $20 \%(\mathrm{~m} / \mathrm{v}), \mathrm{pH} 7)$.

The data were collected at the X06DA PXIII beamline at the Swiss Light Source (Villigen, Switzerland), equipped with a PILATUS 2M detector and the multiaxis PRIGo goniometer ${ }^{21}$. The wavelength was $1.00 \AA$, with a flux at full transmission of $4 \cdot 10^{11}$ photons $\cdot \mathrm{s}^{-1}$. The data were collected with two rotations of $360^{\circ}$ at $\chi=0^{\circ}$ and $\chi=30^{\circ}\left(0.2^{\circ}\right.$ and $0.1 \mathrm{~s}$ per frame). The crystal-to-detector distance was $300 \mathrm{~mm}$. The data were processed and merged using the software autoPROC version 1.0.5 ${ }^{22}$ and STARANISO (Cambridge, United Kingdom: Global Phasing Ltd) ${ }^{23}$. The structures were solved by molecular replacement using the software MOLREP version 11.4.04 ${ }^{24}$ and search models $1 \mathrm{OK} 7$ for the E. coli cases and 4TR7 for the M. tuberculosis cases. Refinement was performed with BUSTER version 2.10.3 (Cambridge, United Kingdom: Global Phasing Ltd) and phenix.refine version 1.10.1-2155 ${ }^{25}$, with NCS constraints for all structures and TLS for both higher resolution E. coli structures. Secondary structure restraints were additionally imposed in phenix.refine for the Mtwt-P7 structure. $5 \%$ of reflections were set aside for the $R_{\text {free }}$ test set. 
Data processing and refinement statistics are available in SI.9 The 4 structures ${ }^{E c w t}{ }^{S C / \mathbf{P}_{7}}$, ${ }^{E c \mathrm{M} 1} \mathrm{SC} / \mathbf{P}_{7},{ }^{\mathrm{M} t \mathrm{wt}} \mathrm{SC} / \mathbf{P}_{7}$ and ${ }^{M t \mathrm{M} 1} \mathrm{SC} / \mathbf{P}_{7}$ are deposited in the Protein Data Bank (PDB) under the respective accession codes $6 \mathrm{FVL}, 6 \mathrm{FVM}, 6 \mathrm{FVN}$ and $6 \mathrm{FVO}$. No complex structure could be solved for any ${ }^{B s} \mathrm{SC}$.

The solvent accessible surface area was calculated using AREAIMOL in CCP4 ${ }^{26}$. The difference in accessible surface area of a binding pocket with and without $\mathbf{P}_{7}$ was obtained by considering the structures from this work and from Wolff et al. ${ }^{18}$ (PDB codes 1OK7 for ${ }^{E c w t} \mathrm{SC}$ and $4 \mathrm{TR} 7$ for $\left.{ }^{\mathrm{Mtwt}} \mathrm{SC}\right)$.

\section{Replication assays.}

Escherichia coli Pol III* purification. E. coli strain BLR transformed with pHOC2.6.1 (kindly provided by $\mathrm{C}$. McHenry), coding for all the 8 polIII subunits, were grown at $37^{\circ} \mathrm{C}$ in $\mathrm{LB}$ buffer supplemented with $100 \mu \mathrm{g} / \mathrm{ml}$ carbenicillin to reach an OD600nm of about 0.65 , transferred to $30^{\circ} \mathrm{C}$ and then expression of Pol III* subunits was started by adjunction of 1 $\mathrm{mM}$ IPTG and extended for $3 \mathrm{~h}$. Cell pellets $(16.8 \mathrm{~g})$ were stored at $-20^{\circ} \mathrm{C}$ overnight. Purification of PolIII* was conducted essentially as described previously ${ }^{27}$. Briefly, pellets thawed at $4^{\circ} \mathrm{C}$ for $30 \mathrm{~min}$ were resuspended in $50 \mathrm{ml}$ of $50 \mathrm{mM}$ Hepes- $\mathrm{KOH} \mathrm{pH} 7.5,10 \%$ $(\mathrm{m} / \mathrm{v})$ sucrose, $10 \mathrm{mM}$ DTT. $5 \mathrm{ml}$ of lysis buffer $(50 \mathrm{mM}$ Hepes-KOH pH 7.5, $10 \%$ (m/v) sucrose, $2 \mathrm{M} \mathrm{NaCl}, 0.3 \mathrm{M}$ spermidine) were added to the cell suspension and Tris base $2 \mathrm{M}$ was used to adjust to $\mathrm{pH}$ 8. Lysis was performed on ice for $1 \mathrm{~h}$ after addition of lysosyme to $0.2 \mathrm{mg} / \mathrm{ml}$. After centrifugation at $20000 \mathrm{rpm}$ for 1 hour at $4^{\circ} \mathrm{C}$ ( Beckmann $70 \mathrm{Ti}$ rotor), proteins were precipitated by slow addition of $0.226 \mathrm{~g} / \mathrm{ml}$ ammonium sulfate and incubation $30 \mathrm{~min}$ at $4^{\circ} \mathrm{C}$ with agitation. After centrifugation $\left(45 \mathrm{~min}, 16000 \mathrm{rpm}, 4^{\circ} \mathrm{C}\right.$ ), pellet was successively extracted with $3.275 \mathrm{ml}$ of buffer A (25 mM Hepes-KOH pH 7.5, $5 \%(\mathrm{v} / \mathrm{v})$ glycerol, $100 \mathrm{mM} \mathrm{KCl,} 1 \mathrm{mM}$ EDTA, $5 \mathrm{mM}$ DTT) supplemented with $0.2 \mathrm{~g} / \mathrm{ml}$ ammonium sulfate, centrifuged, and further extracted with $1.2 \mathrm{ml}$ of buffer A with $0.7 \mathrm{~g} / \mathrm{ml}$ ammonium sulfate. After centrifugation ( $20 \mathrm{~min}, 30,000 \mathrm{rpm}, 4^{\circ} \mathrm{C}$ ), the pellet was resuspended in buffer A without $\mathrm{KCl}$ and conductivity was adjusted to the one of buffer B (25 mM Hepes-KOH pH 7.5, 5\% (v/v) glycerol, $20 \mathrm{mM} \mathrm{KCl,} 1 \mathrm{mM}$ EDTA, $5 \mathrm{mM}$ DTT), then loaded onto a SP sepharose column ( $1 \mathrm{ml}$, GE Healthcare) equilibrated with buffer B and developed with a linear gradient of 0 to $30 \%$ buffer $\mathrm{C}(25 \mathrm{mM}$ Hepes-KOH pH 7.5, 5\% (v/v) glycerol, $1 \mathrm{M}$ $\mathrm{KCl}, 1 \mathrm{mM}$ EDTA, $5 \mathrm{mM}$ DTT) on AKTA smart chromatography system (GE Healthcare). 
Finally, pooled fractions were buffer exchanged for buffer D (25 mM Hepes-KOH pH 7.5, $5 \%$ (v/v) glycerol, $20 \mathrm{mM} \mathrm{KCl}, 5 \mathrm{mM}$ DTT) on a PD10 column (GE Healthcare) and concentrated by ultra-filtration on Amicon Ultra centrifugal units (MWCO 10K), adjusted to $50 \%(\mathrm{v} / \mathrm{v})$ glycerol and to $0.21 \mathrm{mg}$ of protein per $\mathrm{ml}$ and stored at $-80^{\circ} \mathrm{C}$.

Bacillus subtilis minimal replicase (BsP) was reconstitued by assembly of purified proteins (kindly provided by Charles McHenry and Paul R. Dohrmann) at ratio of 1 PolC, 5 tau, 1.25 delta and 1.25 delta' to provide a $1.25 \mu \mathrm{M}$ enzyme complex in buffer HD (40 mM Tris acetate $\mathrm{pH}=7.8,10 \mathrm{mM} \mathrm{Mg}$ acetate, $3 \mu \mathrm{M}$ zinc sulfate and $0.015 \%$ (v/v) IGEPAL CA-630).

In vitro primer extension assays. Single-stranded pUC118 DNA was annealed to a 5' radiolabeled 40 mer oligonucleotide (5'GCTGGCGAAAGGGGGATGTGCTGCAAGGCGA

TTAAGTTGG3') in $50 \mathrm{mM} \mathrm{NaCl}$ and $15 \mathrm{mM}$ Tris acetate (pH=7.8). All DNA synthesis assays were pre-assembled on ice in RB buffer (HD buffer supplemented with 2 mM DTT, $150 \mathrm{mM}$ K glutamate, $160 \mu \mathrm{g} / \mathrm{ml}$ BSA, $0.5 \%$ (m/v) PEG 8000, $250 \mu \mathrm{M}$ ATP and $100 \mu \mathrm{M}$ each dNTP). Unless specified, each reaction contains 40 fmoles of primed DNA, 100 fmoles of polymerase complex and 100 fmoles, as a dimer, of beta sliding clamp (SC). DNA synthesis assay were performed for $6 \mathrm{~min}$. at $37^{\circ} \mathrm{C}$ before addition of $15 \mu 1$ of $95 \%$ formamide dye loading buffer and heating at $95^{\circ} \mathrm{C}$ for 5 minutes. Radioactive reaction products were analysed by electrophoresis on 6 to $8 \%$ denaturing ( $8 \mathrm{M}$ urea) polyacrylamide gels followed by imaging using a Typhoon FLA 9500 device (GE Healthcare).

P7 primer extension inhibition assays were performed essentially as above except that mixtures of SC (100 fmoles in HD buffer, $1 \mu \mathrm{l})$ and P7 peptide (diluted in HD buffer, $1 \mu \mathrm{l}$ ) were first incubated for $5 \mathrm{~min}$. at RT $\left(20-25^{\circ} \mathrm{C}\right)$ before adding $8 \mu \mathrm{l}$ of primed DNA plus polymerase complex in RB buffer.

\section{Molecular Dynamics.}

\section{Initial Structures:}

Experimental X-Ray structures of ${ }^{E c w t} \mathrm{SC}$ were used as a starting point for the molecular dynamics simulations of the ${ }^{E c w t} \mathrm{SC}$ in complex with a de-acetylated form of $\mathbf{P}_{7}$ (QXDLF, X $=$ Cha). Starting structure for the ${ }^{E c \mathrm{M} 2} \mathrm{SC}\left(\mathrm{M}_{362} \mathrm{~L}\right)$ was constructed from the ${ }^{E c w t} \mathrm{SC}$ by side-chain modification using PyMol. B. Subtilis simulations were constructed from the ${ }^{B s w t} \mathrm{SC}$ structure (PDBID 4TR6, ${ }^{18}$ ) by inserting the appropriate side-chain replacements with PyMoL for the 
mutant ${ }^{B s \mathrm{M} 2} \mathrm{SC}\left(\mathrm{L}_{373} \mathrm{M}\right)$. For both ${ }^{\text {wt }} \mathrm{SC}$ and mutant ${ }^{\mathrm{M} 2} \mathrm{SC}$, the peptide was positioned by superimposition onto $\mathbf{P}_{\mathbf{1}}$ (PDB 1OK7) and $\mathbf{P}_{\mathbf{1}}$ was subsequently removed.

\section{Free-energy perturbation calculation:}

The relative affinities of the ${ }^{\mathrm{wt}} \mathrm{SC}$ and ${ }^{\mathrm{M} 2} \mathrm{SC}$ for the peptide were estimated using free energy perturbation implemented in NAMD ${ }^{28}$ in the following thermodynamic cycle ${ }^{29}{ }^{30}$ :

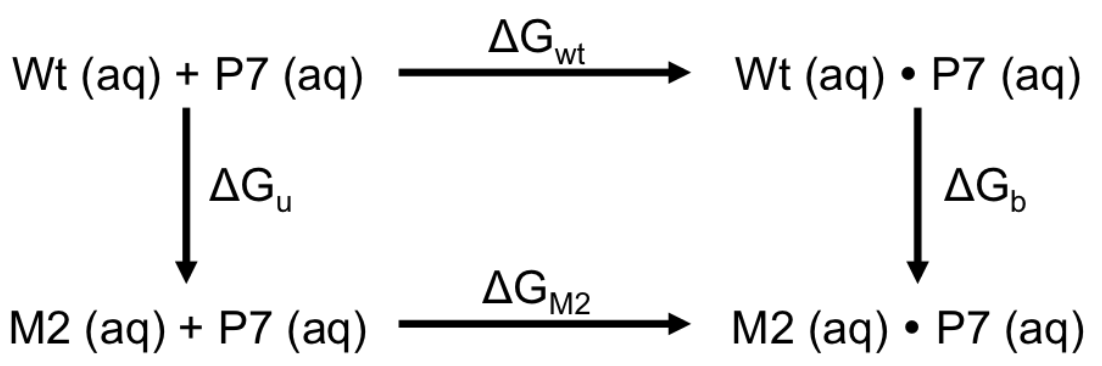

Figure 1: Thermodynamic cycle used in computing the free energy change in the virtual mutation of the ${ }^{\mathrm{wt}} \mathrm{SC}$ into the mutant ${ }^{\mathrm{M} 2} \mathrm{SC}$ in the unbinding form $\left(\Delta \mathrm{G}_{\mathrm{u}}\right)$ and in the binding form $\left(\Delta \mathrm{G}_{\mathrm{b}}\right)$.

These relative affinities, $\Delta \Delta \mathrm{G}$, can be calculated from the following equation:

$$
\Delta \Delta G=\Delta G_{M 2}-\Delta G_{w t}=\Delta G_{b}-\Delta G_{u}
$$

$\Delta \mathrm{G}_{\mathrm{u}}$ and $\Delta \mathrm{G}_{\mathrm{b}}$ are calculated by transforming the Hamiltonian of the initial states (either the apo WT $\left(\Delta \mathrm{G}_{\mathrm{u}}\right)$ or the holo WT $\left.\left(\Delta \mathrm{G}_{\mathrm{b}}\right)\right)$ into the final states (either the apo mutant M2 $\left(\Delta \mathrm{G}_{\mathrm{u}}\right)$ or the holo mutant M2 $\left.\left(\Delta \mathrm{G}_{\mathrm{b}}\right)\right)$. The transformation is modeled by introducing a state variable, $\lambda$, which can vary from 0 (initial state) to 1 (final state). The free-energy calculation is split into small windows, each one involving a small variation of $\lambda$. A new residue is designed to simulate the transformation (for example of the residue $\mathrm{M}_{362}$ into $\mathrm{L}_{362}$ ). In that way, we have built a new residue, name M2L, which includes the atoms of the side chains of a methionine and of a leucine. The structure was then generated by using the force field (FF) charmm $27^{31}$ and was immersed in a tetragonal box filled with TIP3 water molecule and $24 \mathrm{Na}^{+}$ions to neutralize the total charge of the full system. The simulation was then heated at $300 \mathrm{~K}$ and equilibrated before the free-energy perturbation calculation.

\section{RESULTS AND DISCUSSION.}


We have previously observed that peptides initially designed to bind ${ }^{E c} \mathrm{SC}$ with high affinities poorly interact with ${ }^{M t} \mathrm{SC}$ and ${ }^{B s} \mathrm{SC}$, although the binding pockets of all $\mathrm{SC}$ are structurally highly homologous ${ }^{18}$. In order to decipher the molecular basis of these different binding processes, we determined the thermodynamic parameters of the interaction between a reference ligand, namely peptide $\mathbf{P}_{7}$ (SI.2 and SI.10) and different variants of ${ }^{E c} \mathrm{SC},{ }^{M t} \mathrm{SC}$ and ${ }^{B s} \mathrm{SC}$ (Table 1).

\section{Peptide $\mathbf{P}_{7}$ differentially interacts with natural SC from different bacteria.}

We first determined the thermodynamic profiles at different temperatures of $\mathbf{P}_{\mathbf{7}}$ binding on natural SC, namely ${ }^{E c w t} S C$, ${ }^{M t w} \mathrm{SC}$ and ${ }^{B s w t} \mathrm{SC}$, (Figure 1). For each $\mathrm{SC} / \mathbf{P}_{7}$ interaction, global thermodynamic treatment (GTT) ${ }^{32}$ of all experiments at all temperatures yielded theoretical curves describing the evolution of each thermodynamic parameters with temperature (Figure 1, left column). Thermodynamic profiles are inferred from these curves (Figure 1, right column). The profiles observed with the three natural SC are very different (Figure 1, see also SI.5 for a comparison between GTT and individual analysis of ITC raw data and SI.6 for numerical data).

The ${ }^{E c w t}{ }_{S C / P_{7}}$ interaction is enthalpy driven, with a significant increase of the enthalpic contribution from -10 to $-14 \mathrm{kcal} / \mathrm{mole}$ when temperature rises from 15 to $34^{\circ} \mathrm{C}$. This enthalpic contribution is much weaker for the ${ }^{M t \mathrm{wt}} \mathrm{SC}$ (-4 to $-8 \mathrm{kcal} / \mathrm{mol}$ ), and for ${ }^{B s w t} \mathrm{SC}$ (-6 to $-3 \mathrm{kcal} / \mathrm{mol}$ ) over the same range of temperature (Figure 1 right column, SI.5). Nevertheless, the binding process is still enthalpy-driven for ${ }^{M t w t} \mathrm{SC}$ and ${ }^{B s w t} \mathrm{SC}$. The $\Delta \mathrm{Cp}$ $(\partial \Delta \mathrm{H} / \partial \mathrm{T})$ values are $-210 \mathrm{cal} / \mathrm{mol} / \mathrm{deg}$ for $\mathbf{P}_{7}$ binding onto ${ }^{E c w t} \mathrm{SC},-180 \mathrm{cal} / \mathrm{mole} / \mathrm{deg}$ with ${ }^{M t w t} \mathrm{SC}$. The $\Delta \mathrm{Cp}$ for ${ }^{B s w t} \mathrm{SC}$ was not reliably determined. $\mathbf{P}_{\mathbf{7}}$ interaction with ${ }^{E c \mathrm{wt}} \mathrm{SC}$ shows an unfavorable entropic contribution $(-\mathrm{T} \Delta \mathrm{S})$ which increases with temperature (Figure 1A and SI.5). For ${ }^{\text {Bswt }} \mathrm{SC}$, this contribution is weaker and becomes favorable above $25^{\circ} \mathrm{C}$ (Figure 1B), while for. ${ }^{M t w t} \mathrm{SC}$, it evolves in an opposite way (Figure 1C). The Gibb's free energy, $\Delta \mathrm{G}$, also varies significantly between the different complexes. For ${ }^{E c \mathrm{wt}} \mathrm{SC}$, it reaches $-9 \mathrm{kcal} / \mathrm{mole}$ and slightly increases with higher temperatures (Figure 1 and SI.5). It reaches about -5 and -7 $\mathrm{kcal} / \mathrm{mole}$ for ${ }^{B s \mathrm{wt}} \mathrm{SC}$ and ${ }^{\mathrm{Mtwt}} \mathrm{SC}$, respectively, indicative of a weaker interaction between $\mathbf{P}_{7}$ and these two SC, and in both cases, it varies very slightly over the range of temperature. Interestingly, $\Delta \mathrm{G}$ reaches a maximum at $18^{\circ} \mathrm{C}$ for ${ }^{B s w t} \mathrm{SC} / \mathbf{P}_{7}$ and a minimum at $29^{\circ} \mathrm{C}$ for ${ }^{\mathrm{M} w \mathrm{w} t} \mathrm{SC} / \mathbf{P}_{\mathbf{7}}$ interactions due to the null value of $\Delta \mathrm{S}$ at these temperatures (Figure $\mathbf{1}$ left 
column), implying that around these temperatures, the $\Delta \mathrm{G}$ variation is minimal. For ${ }^{E c w t} \mathrm{SC} / \mathbf{P}_{7}$, extrapolation of the curve $\Delta \mathrm{S}=\mathrm{f}(\mathrm{T})$ indicates that $\Delta \mathrm{S}=0$ at $\mathrm{T}<0^{\circ} \mathrm{C}$.

\begin{tabular}{|c|c|c|c|c|c|c|}
\hline & \multicolumn{2}{|c|}{ E. coli } & \multicolumn{2}{|c|}{ M. tuberculosis } & \multicolumn{2}{|c|}{ B. subtilis } \\
\hline & Name & Amino acids & Name & Amino acids & Name & Amino acids \\
\hline wt & ${ }^{E c w t} \mathrm{SC}$ & $\mathrm{S}_{346} ; \mathrm{M}_{362}$ & ${ }^{\text {Mtwt }} \mathrm{SC}$ & $\mathrm{P}_{362 ;} \mathrm{M}_{396}$ & ${ }^{B s w t} \mathrm{SC}$ & $\mathrm{P}_{357 ;} \mathrm{L}_{373}$ \\
\hline M1 & ${ }^{E c \mathrm{Ml}} \mathrm{SC}$ & $\mathrm{P}_{346} ; \mathrm{M}_{362}$ & ${ }^{M t \mathrm{Ml}} \mathrm{SC}$ & $\mathrm{S}_{362 ;} \mathrm{M}_{396}$ & ${ }^{B S M I} \mathrm{SC}$ & $\mathrm{S}_{357 ;} \mathrm{L}_{373}$ \\
\hline M2 & ${ }^{E c \mathrm{M} 2} \mathrm{SC}$ & $\mathrm{S}_{346} ; \mathrm{L}_{362}$ & ${ }^{M t \mathrm{M} 2} \mathrm{SC}$ & $\mathrm{P}_{362 ;} \mathrm{L}_{396}$ & ${ }^{B S M 2} \mathrm{SC}$ & $\mathrm{P}_{357 ;} \mathrm{M}_{373}$ \\
\hline M3 & ${ }^{E c \mathrm{M} 3} \mathrm{SC}$ & $\mathrm{P}_{346} ; \mathrm{L}_{362}$ & - & - & ${ }^{B S M 3} \mathrm{SC}$ & $\mathrm{S}_{357 ;} \mathrm{M}_{373}$ \\
\hline G1 & ${ }^{E c G 1} \mathrm{SC}$ & $\mathrm{G}_{346} ; \mathrm{M}_{362}$ & - & - & ${ }^{B s G l} \mathrm{SC}$ & $\mathrm{G}_{357 ;} \mathrm{L}_{373}$ \\
\hline G2 & ${ }^{E c \mathrm{G} 2} \mathrm{SC}$ & $\mathrm{S}_{346} ; \mathrm{G}_{362}$ & - & - & ${ }^{B s \mathrm{G} 2} \mathrm{SC}$ & $\mathrm{P}_{357 ;} \mathrm{G}_{373}$ \\
\hline
\end{tabular}

Table 1: Names and sequences characteristics of the different sliding clamps used in this study. $E c$ : Escherichia coli; Mt: Mycobacterium tuberculosis; Bs: Bacillus subtilis; wt: wild type sliding clamps; M1, M2, M3, G1 and G2: mutant sliding clamps.

The dissociation constant measured for ${ }^{E c \mathrm{wt}} \mathrm{SC} / \mathbf{P}_{7}$ interaction increases from 100 to $450 \mathrm{nM}$ between 15 and $34^{\circ} \mathbf{C}$ (Table 2, Figure 1A and SI.6). For the ${ }^{\mathrm{Mtwt}} \mathrm{SC} / \mathbf{P}_{7}$ interaction, the $\mathrm{Kd}$ is about 20 to 40 times lower (between 4 and $7 \mu \mathrm{M}$ ), while the lowest affinity is observed for ${ }^{\mathrm{Bswt}} \mathrm{SC}$, with $\mathrm{Kd}$ values ranging from 40 to $80 \mu \mathrm{M}$ range.

All these data confirm our previous observations and show that $\mathbf{P}_{\mathbf{7}}$ binding greatly vary with the SC bacterial origin ${ }^{18}$. To investigate the molecular basis of these differences, we constructed several mutants of each SC where the residues corresponding to ${ }^{E c w t}{ }^{S C ~} S_{346}$ and ${ }^{\text {Ecwt }}{ } \mathrm{SC} \mathrm{M}_{362}$ are singly (M1, M2, G1 and G2 respectively) or both (M3) mutated (Table 1). The interaction of $\mathbf{P}_{7}$ with these SC variants was analyzed using ITC, crystal structures, in vitro replication assays and molecular modeling analyses. 
A.
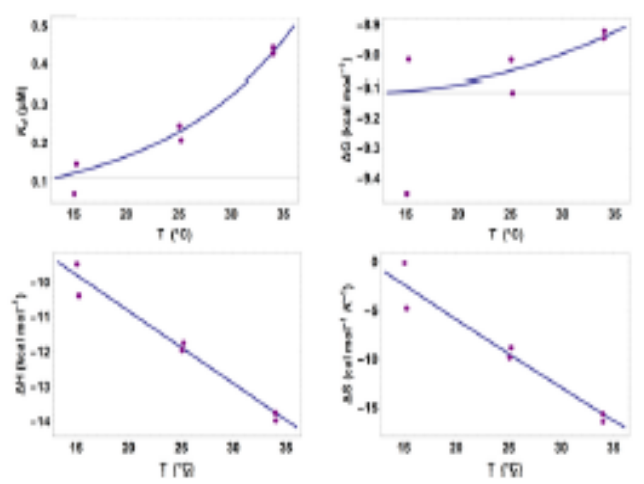

B.
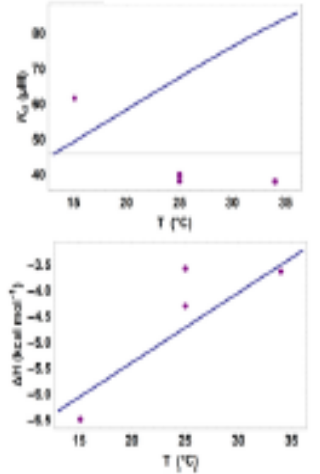

C.
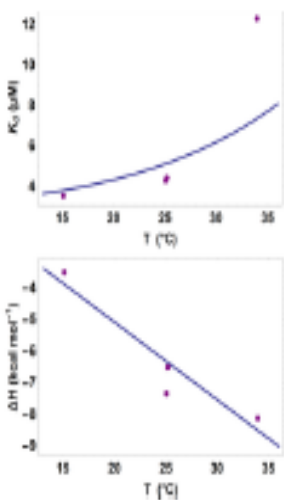

$15^{\circ} \mathrm{C}$ $25^{\circ} \mathrm{C}$ $34^{\circ} \mathrm{C}$

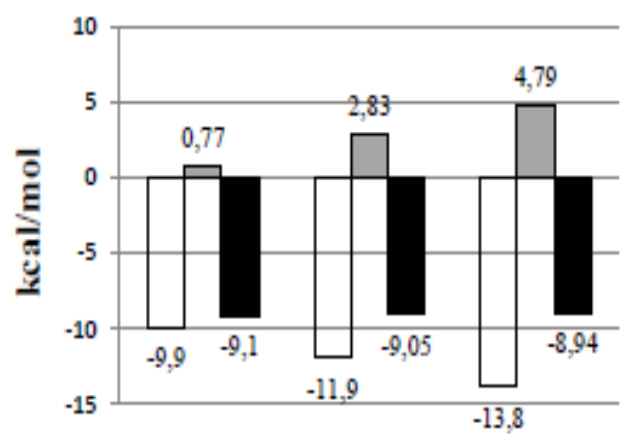

$15^{\circ} \mathrm{C}$

$25^{\circ} \mathrm{C}$

$34^{\circ} \mathrm{C}$
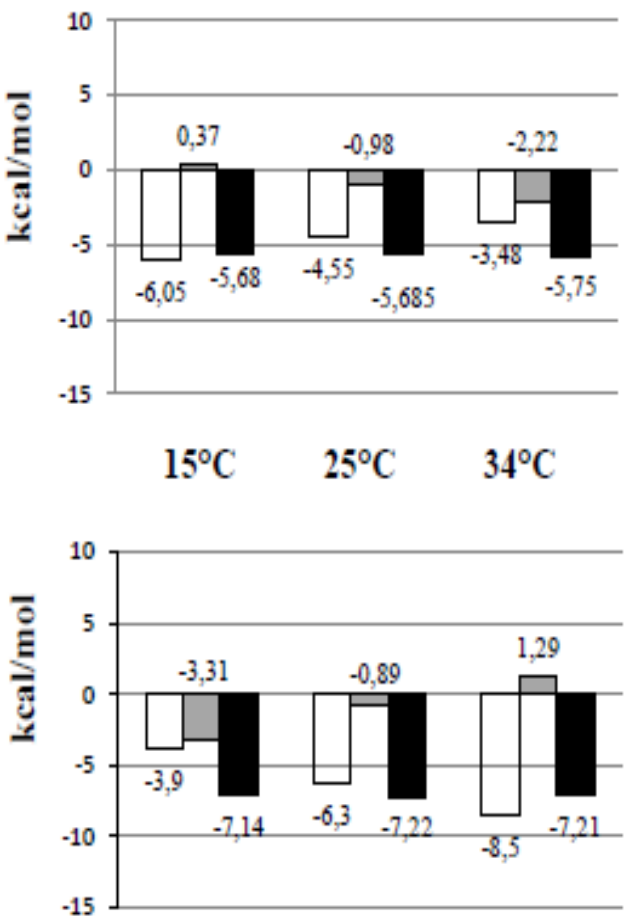

Figure 1: Thermodynamic analyses of $\mathbf{P}_{7}$ interaction with ${ }^{E c w t} \mathrm{SC}(\mathrm{A}),{ }^{B s w t} \mathrm{SC}$ (B) and ${ }^{M t w t} \mathrm{SC}$ (C) at different temperatures. Global thermodynamic treatment (GTT) (left column): The curves represent the functions obtained by treating simultaneously all experimental ITC data at three temperatures. Dots represent the results of a classical treatment of each experimental ITC data processed individually. For weak interaction, such as ${ }^{\text {Bswt }} \mathrm{SC} / \mathbf{P}_{\mathbf{7}}$, the gap between individual treatment and the theoretical curve obtained by GTT is more important. Thermodynamics profiles (right column) displaying $\Delta \mathrm{H},-\mathrm{T} \Delta \mathrm{S}$ and $\Delta \mathrm{G}$ at three temperatures were obtained from the GTT derived curves. $\Delta \mathrm{H},-\mathrm{T} \Delta \mathrm{S}$ and $\Delta \mathrm{G}$ (all in kcal/mol) are white, grey and dark bars, respectively. All ITC data are presented in SI.6 and typical ITC titration curves are shown in SI.7. ITC control experiments at three temperatures are presented in SI.4. 


\begin{tabular}{|c|c|c|c|c|}
\hline & & $\mathbf{1 5}^{\circ} \mathbf{C}(\mathbf{2 8 8 . 1 5} \mathbf{~ K})$ & $\mathbf{2 5}^{\circ} \mathbf{C}(\mathbf{2 9 8 . 1 5} \mathbf{~ K})$ & $\mathbf{3 4}^{\circ} \mathbf{C}(\mathbf{3 0 7 . 1 5} \mathbf{~ K})$ \\
\hline \multirow{3}{*}{${ }^{E c w t} \mathbf{S C}$} & Classical processing & $0.09( \pm 0.04)$ & $0.16( \pm 0.05)$ & $0.42( \pm 0.04)$ \\
\cline { 2 - 5 } & GTT processing & 0.12 & 0.22 & 0.44 \\
\hline \multirow{3}{*}{${ }^{B s w t} \mathbf{S C}$} & Classical processing & $24( \pm 18)$ & $14( \pm 0.6)$ & $43( \pm 49)$ \\
\cline { 2 - 5 } & GTT processing & 49 & 68 & 82 \\
\hline \multirow{2}{*}{${ }^{\boldsymbol{M} t w \mathbf{w}} \mathbf{S C}$} & Classical processing & $3.5( \pm 3)$ & $5( \pm 3.9)$ & $7.23( \pm 1)$ \\
\cline { 2 - 5 } & GTT processing & 4 & 5 & 7 \\
\hline
\end{tabular}

Table 2: Dissociation constants $\left(K_{D}: \mu M\right)$ of the $P_{7}$ interaction with the three natural $S C$ at different temperatures. The large standard deviations observed for ${ }^{B s w} \mathrm{SC}$ and ${ }^{M t w t} \mathrm{SC}$ are indicative of a poor interaction. Independent experiments were performed two to four times. All results were obtained through classical or GTT processing of experimental data, as indicated. Full thermodynamic data are in SI.6 and examples of ITC titration curves are presented in SI.7.

\section{Mutations $\mathrm{S}_{346} \mathrm{P}$ and $\mathrm{M}_{362} \mathrm{~L}$ in ${ }^{E c w t} \mathrm{SC}$ drastically modify the thermodynamics of $\mathrm{SC} / \mathrm{P}_{7}$ interaction.}

Complete thermodynamic profiles of $\mathbf{P}_{7}$ interaction with the various SC mutants are presented in SI.8 and SI.11. Figure 2 presents a comparison of the thermodynamics profiles of the $\mathbf{P}_{7}$ interaction with ${ }^{E c w t} \mathrm{SC}$ and the double mutant ${ }^{E c \mathrm{M} 3} \mathrm{SC}$. Details on the specific effects induced by single mutations are developed in SI.11. Introduction of the $\mathrm{S}_{346} \mathrm{P}$ and $\mathrm{M}_{362} \mathrm{~L}$ mutations in the ${ }^{E c w t} \mathrm{SC}$ binding pocket results in a large reduction of $|\Delta \mathrm{H}|$ of about +6 $\mathrm{kcal} / \mathrm{mol}$ at $15^{\circ} \mathrm{C}$ and $+10 \mathrm{kcal} / \mathrm{mol}$ at $34^{\circ} \mathrm{C}$. The resulting $\Delta \mathrm{Cp}$ drops from $-210\left({ }^{E c w t} \mathrm{SC}\right)$ to $50 \mathrm{cal} / \mathrm{mol} / \mathrm{deg}$ for ${ }^{E c \mathrm{M} 3} \mathrm{SC}$, indicative of a change in the mode of interaction ${ }^{33}$. As opposed to what is observed with ${ }^{E c w t} \mathrm{SC}$, the entropic component $(-\mathrm{T} \Delta \mathrm{S})$ becomes favorable $(\approx-2$ to -3 $\mathrm{kcal} / \mathrm{mol}$ ) to the ${ }^{E c \mathrm{M} 3} \mathrm{SC} / \mathbf{P}_{7}$ interaction at all temperatures. The resulting free energy of interaction, $\Delta \mathrm{G}$, is stabilized around -6 to $-7 \mathrm{kcal} / \mathrm{mol}$, i.e. about $2-3 \mathrm{kcal} / \mathrm{mol}$ higher that those observed for ${ }^{E c w t} \mathrm{SC}$, at all temperatures. Consequently, the mutations $\mathrm{S}_{346} \mathrm{P}$ and $\mathrm{M}_{362} \mathrm{~L}$ in ${ }^{E c w t} \mathrm{SC}$ trigger a drastic change in the $\mathbf{P}_{\mathbf{7}}$ mode of interaction, underlying the significant contribution of these residues to the efficient binding of $\mathbf{P}_{7}$ on ${ }^{E c w t} \mathrm{SC}$. 


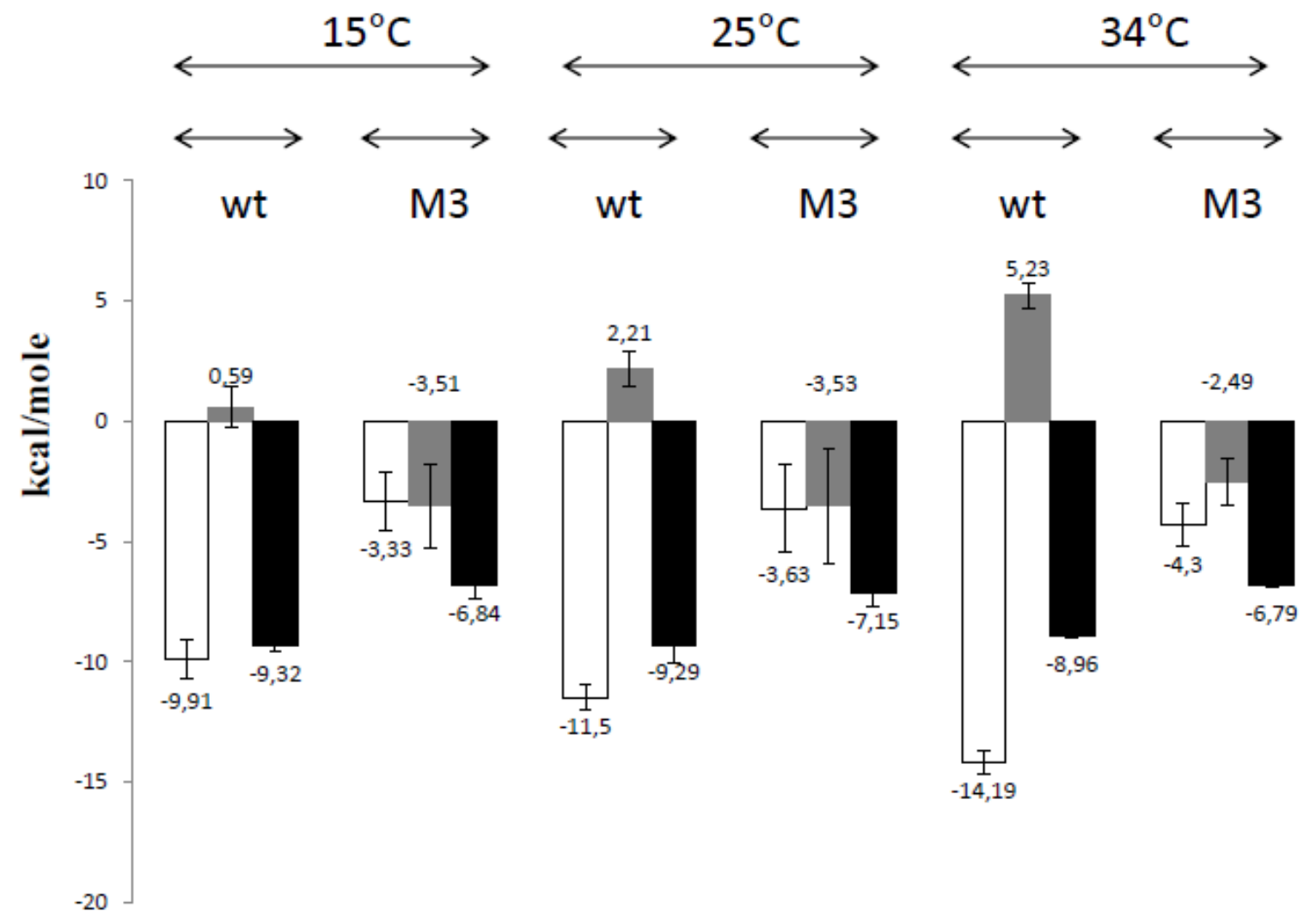

Figure 2: Thermodynamic profiles of $\mathrm{P}_{7}$ interactions with ${ }^{E c w t} \mathrm{SC}$ (wt) and ${ }^{E c \mathrm{M} 3} \mathrm{SC}$ (M3) at different temperatures. $\Delta \mathrm{H},-\mathrm{T} \Delta \mathrm{S}$ and $\Delta \mathrm{G}($ all in $\mathrm{kcal} / \mathrm{mol})$ are white, grey and dark bars, respectively. Data are means of at least two independent experiments. For the sake of comparison, all results are obtained through classical processing of experimental data (SI.6).

\section{${ }^{E c M 3} \mathrm{SC}$ and ${ }^{B s w t} \mathrm{SC}$ present similar thermodynamic profiles upon $\mathbf{P}_{7}$ interaction.}

Because the two mutations introduced in ${ }^{E c \mathrm{M} 3} \mathrm{SC}$ are equivalent to the natural residues found in ${ }^{B s w t} \mathrm{SC}$ (Table 1), we also compared the thermodynamic profiles obtained for $\mathbf{P}_{\mathbf{7}}$ interaction with ${ }^{E c \mathrm{M} 3} \mathrm{SC}$ and ${ }^{B s w t} \mathrm{SC}$ (Figure 3). These profiles are very similar at all temperatures, confirming that the introduction of $\mathrm{S}_{346} \mathrm{P}$ and $\mathrm{M}_{362} \mathrm{~L}$ mutations in ${ }^{E c w t} \mathrm{SC}$ is sufficient to convert the $E$. coli specific thermodynamic profile into that observed with ${ }^{B s w t} \mathrm{SC}$. For both types of interactions, the enthalpic contribution is equivalent, ranging from -3 to -4 $\mathrm{kcal} / \mathrm{mole}$, and in both cases, the entropic contributions are favorable to the interaction, around $-3 \mathrm{kcal} / \mathrm{mol}$. The large variations of both parameters result from the poor efficiency of the peptide binding. The resulting free energy of interaction is slightly more favorable for ${ }^{E c \mathrm{M} 3} \mathrm{SC} / \mathbf{P}_{\mathbf{7}}$ than for ${ }^{B s w t} \mathrm{SC} / \mathbf{P}_{\mathbf{7}}$, suggesting that besides the contributions of $\mathrm{S}_{346}$ and $\mathbf{M}_{362}$ 
residues, the local environment of the ${ }^{E c} \mathrm{SC}$ pocket stabilizes the peptide interaction more significantly than that of ${ }^{B s w t} \mathrm{SC}$.

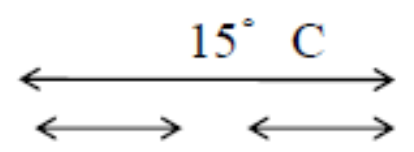

M3

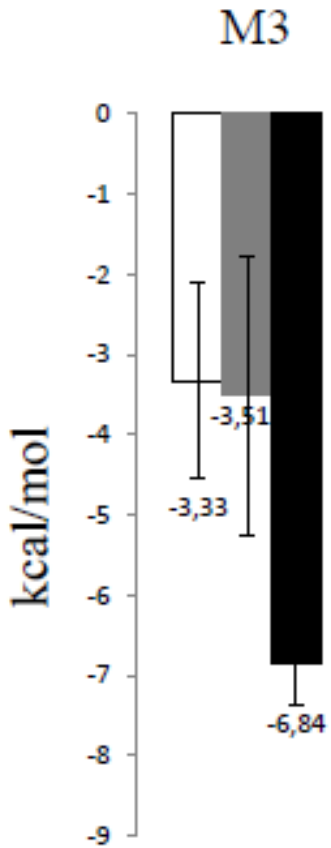

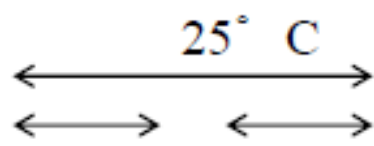

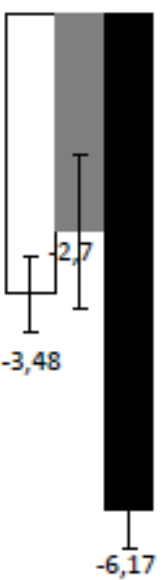

M3

wt

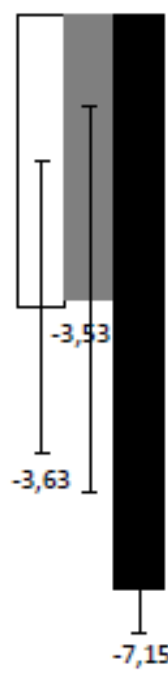

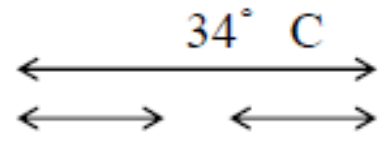

M3 wt
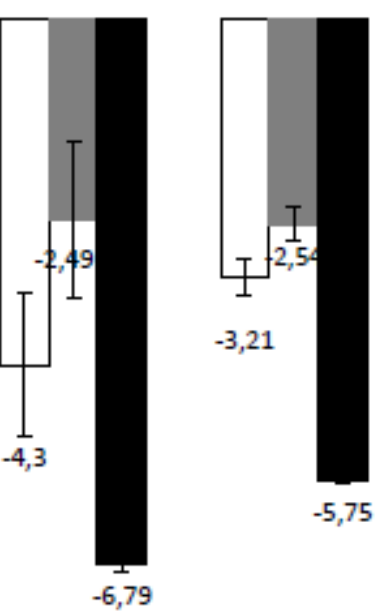

Figure 3: Thermodynamic profiles of $\mathrm{P}_{7}$ interactions with ${ }^{E c \mathrm{M} 3} \mathrm{SC}(\mathrm{M3})$ and ${ }^{B s w t} \mathrm{SC}$ (wt) at different temperatures. $\Delta \mathrm{H},-\mathrm{T} \Delta \mathrm{S}$ and $\Delta \mathrm{G}$ (all in $\mathrm{kcal} / \mathrm{mol})$ are white, grey and black bars, respectively. Data are means of at least two independent experiments. Results are obtained through classical processing of experimental data (SI.6).

\section{Mutations $\mathbf{P}_{357} S$ and $\mathrm{L}_{373} \mathrm{M}$ residues in ${ }^{B s w t} \mathrm{SC}$ improve $\mathbf{P}_{7}$ interaction.}

We also analyzed the effects of the introduction of $E c$ natural residues $\left(\mathrm{S}_{346}\right.$ and $\left.\mathrm{M}_{362}\right)$ in the $B s$ context (Figure 4, SI.8 $\mathbf{B}$ and SI.11 B for details on single mutations effects on $\mathbf{P}_{7}$ interaction). As opposed to the major deleterious effect on complex formation triggered by mutations introduced in ${ }^{E c \mathrm{wt}} \mathrm{SC}$ (Figure 2), the mutations of the corresponding residues in ${ }^{B s} \mathrm{SC}$ improve the efficiency of the interaction with $\mathbf{P}_{\mathbf{7}}$, as indicated by the systematic increase of $\Delta \mathrm{G}$ values with ${ }^{B s \mathrm{M} 3} \mathrm{SC}$ as compared to ${ }^{B s w t} \mathrm{SC}$ (Figure 4). However, the effect is limited as these $\Delta \mathrm{G}$ values remain about $2 \mathrm{kcal} /$ mole lower than those measured for ${ }^{E c w t} \mathrm{SC}$. This is in agreement with the above mentioned observation that the ${ }^{B s} \mathrm{SC}$ pocket might be globally less favorable to $\mathbf{P}_{\mathbf{7}}$ binding. Consequently, as observed for the $E c$ context (SI.11 A) but with opposite effects, these mutations differentially trigger a change in the thermodynamic profiles 
of the interaction (SI.11 B). At all temperatures, the $\mathrm{P}_{357} \mathrm{~S}$ mutation (mutant ${ }^{B s \mathrm{M} 1} \mathrm{SC}$ ) triggers a reduction of the $\Delta \mathrm{H}$ values, as compared to those measured in ${ }^{B s w t} \mathrm{SC}$, and an increase of the entropic factor favorable contribution. Alternatively, the $\mathrm{L}_{373} \mathrm{M}$ mutation (mutant ${ }^{B s \mathrm{M} 2} \mathrm{SC}$ ) increases the $\Delta \mathrm{H}$ value by -3 to $-5 \mathrm{kcal} / \mathrm{mol}$ at each temperature and drastically reduces the entropic contribution, which becomes unfavorable at high temperature.

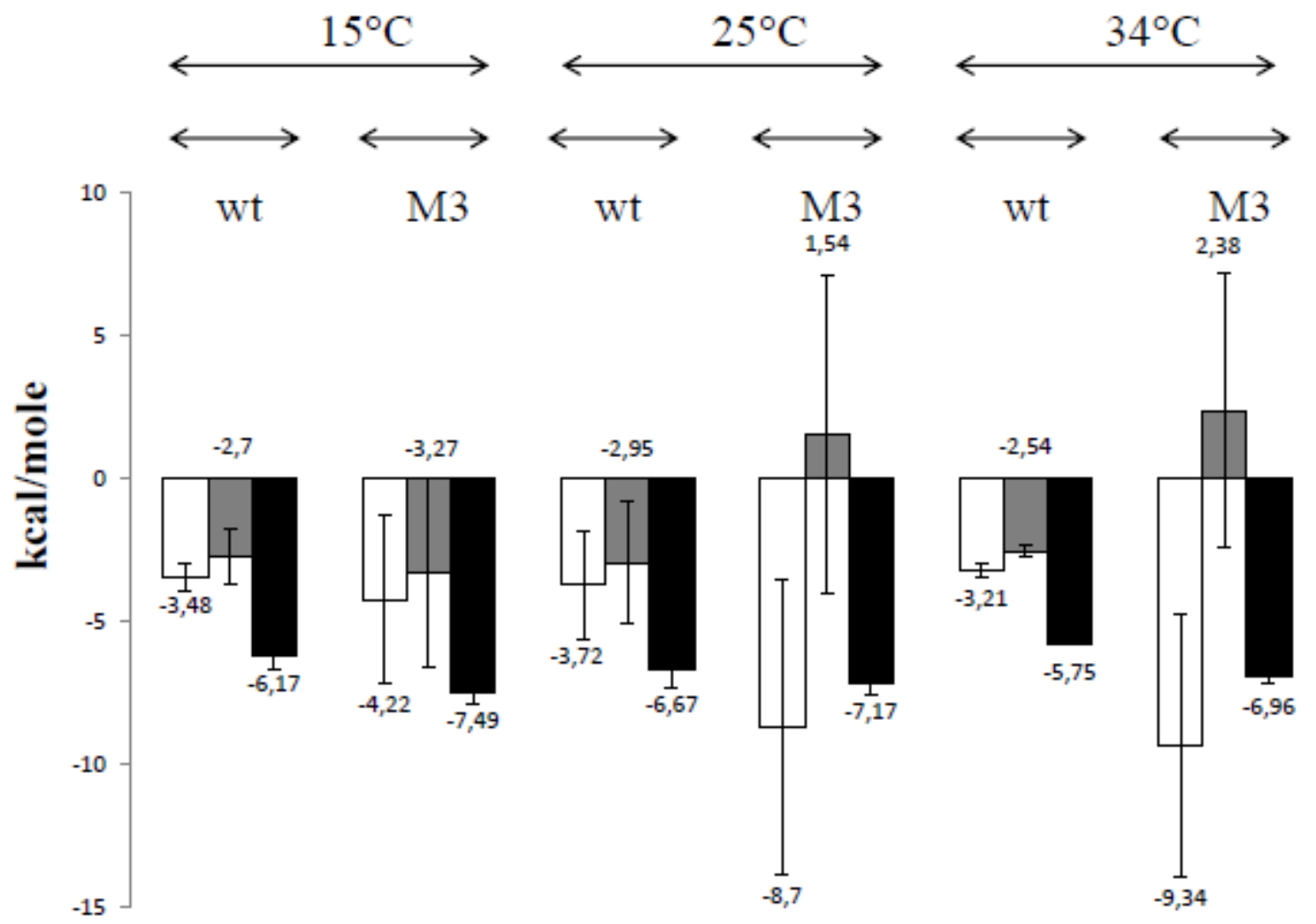

Figure 4 : Thermodynamic profiles of $\mathrm{P}_{7}$ interactions with ${ }^{B s w t} \mathrm{SC}(\mathrm{wt})$ and ${ }^{B s \mathrm{M} 3} \mathrm{SC}(\mathrm{M} 3)$ at different temperatures. $\Delta \mathrm{H},-\mathrm{T} \Delta \mathrm{S}$ and $\Delta \mathrm{G}($ all in $\mathrm{kcal} / \mathrm{mol})$ are white, grey and black bars, respectively. Data are means of at least two independent experiments. Results are obtained through classical processing of experimental data (SI.6).

The added contribution of both mutations, measured with mutant $B s \mathrm{M} 3$, combine the effects of each individual mutation. As a result, the $\Delta \mathrm{H}$ evolution becomes strongly dependent on temperature and the entropic contribution turns to be unfavorable at $34^{\circ} \mathrm{C}$ for both $\mathrm{M} 2$ and M3 mutants (SI.11 B), but already at $25^{\circ} \mathrm{C}$ for the double mutant, which suggests a synergistic effect of both mutations (Figure 4). Indeed, the $\triangle \mathrm{Cp}$ value determined for ${ }^{B s M 3} \mathrm{SC}$ $(-270 \mathrm{cal} / \mathrm{mole} / \mathrm{deg})$ is closed to that measured for ${ }^{E c w t} \mathrm{SC}(-210 \mathrm{cal} / \mathrm{mole} / \mathrm{deg})$, whereas the values calculated for ${ }^{B s \mathrm{M} 1} \mathrm{SC}$ and ${ }^{B s \mathrm{M} 2} \mathrm{SC}$ are -10 and $-40 \mathrm{cal} / \mathrm{mol} / \mathrm{deg}$, respectively. These 
observations show that the two mutations, $\mathrm{P}_{357} \mathrm{~S}$ and $\mathrm{L}_{373} \mathrm{M}$, induce a complete change of the thermodynamic profile of the ${ }^{B s} \mathrm{SC} / \mathbf{P}_{7}$ interaction. Moreover, in the two different pocket environments, $E c$ and $B s$, the drastic changes in thermodynamic profiles are triggered by the M2 mutations (Figure SI.11 A and B) thus identifying a strategic position for what concerns the peptide interaction. The position of M1 mutations is not that crucial for the complex formation.

\section{Specific contributions of the strategic residues to the $\mathbf{P}_{7}$ interaction.}

To further analyze the specific contributions of the $\mathrm{S}_{346}$ (or $\mathrm{P}_{346}$ ) and $\mathrm{M}_{362}$ (or $\mathrm{L}_{362}$ ) residues to the $\mathbf{P}_{7}$ interaction, we compared the thermodynamic data obtained for ${ }^{\text {wt }} \mathrm{SC}$ (or ${ }^{\mathrm{M} 1} \mathrm{SC}$ or ${ }^{\mathrm{M} 2} \mathrm{SC}$ ) with those obtained with ${ }^{\mathrm{G} 1} \mathrm{SC}$ and ${ }^{\mathrm{G} 2} \mathrm{SC}$ (Table 1), where the natural residues are replaced by glycine (Figure 5 and SI.12). Note that thermodynamic data obtained with the $\mathrm{G}$ mutants directly provide the whole pocket contribution to the interaction, excluding the $\mathrm{S} / \mathrm{P}$ and $\mathrm{M} / \mathrm{L}$ side chain effects. The specific contributions of the $\mathrm{S} / \mathrm{P}$ and $\mathrm{M} / \mathrm{L}$ residues to each thermodynamic parameter are obtained by the difference between the parameter measured for ${ }^{\text {wt }} \mathrm{SC}$ and that measured for the ${ }^{\mathrm{Gn}} \mathrm{SC}$ (SI.12). The results are presented in Figure 5.

In the $E c$ context, the $S_{346}$ residue does not contribute significantly to the $\mathbf{P}_{7}$ interaction, as indicated by the weak $\Delta \mathrm{G}$ value, particularly at high temperatures (Figure $\mathbf{5 A}$, left). The $\Delta \mathrm{H}$ value reveals an endothermic contribution, while the favorable entropic contribution increases with temperature and might be linked, at least partly, to water release upon peptide interaction, as observed in crystal structures ${ }^{5}$. A very different profile is observed for the $\mathbf{M}_{362}$ residue (Figure 5A, right), with essentially an exothermic specific contribution, no entropic effect and a constant Gibb's free energy ( $-1 \mathrm{kcal} / \mathrm{mole})$ over the temperature range. Thus this residue contributes for about one tenth of the overall interaction of the peptide (see Figure 1A). Mutation $\mathrm{S}_{346} \mathrm{P}$ (Figure 5B, left) presents a similar profile as that observed for the natural residue, with a very weak contribution to binding. In contrast, the profile observed for the $\mathrm{M}_{362} \mathrm{~L}$ mutation (Figure 5B, right) reveals how detrimental is the $\mathrm{L}$ residue at this position to the $\mathbf{P}_{7}$ interaction in the $E c$ context. All together, these residue specific profiles reveal that position 362 in ${ }^{E c} \mathrm{SC}$ significantlycontributes to the binding, while position 346 does not. In addition, the nature of the residue, M vs L, at this very position appears to be crucial for the binding. 


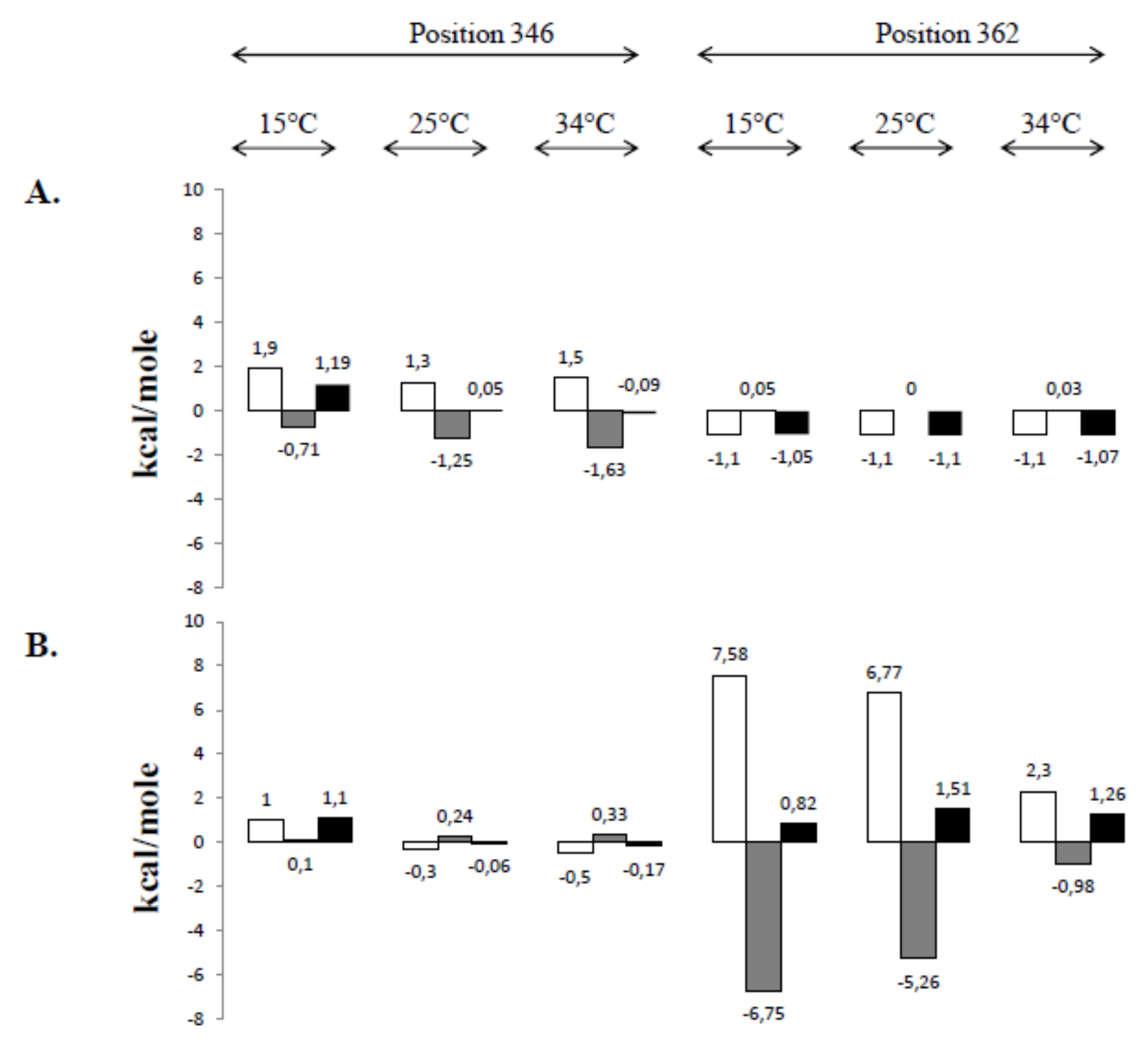

Figure 5: Specific contribution to the $P_{7}$ interaction of residues at positions 346 and 362 in ${ }^{E C} \mathrm{SC}$. (A): contribution of natural residues $\mathrm{S}_{346}$ (left) and $\mathrm{M}_{362}$ (right). The residue specific profiles result from the difference between thermodynamic values for ${ }^{E c} \mathrm{wt}$ and ${ }^{E c} \mathrm{G} 1$ (left) or ${ }^{E c} \mathrm{G} 2$ (right). (B): contribution of non natural residues $\mathrm{P}_{346}$ (left) and $\mathrm{L}_{362}$ (right). The residue specific profiles result from the difference between thermodynamic values for ${ }^{E c} \mathrm{M} 1$ and ${ }^{E c} \mathrm{G} 1$ (left) or ${ }^{E c} \mathrm{M} 2$ and ${ }^{E c} \mathrm{G} 2$ (right) (SI.12). $\Delta \mathrm{H},-\mathrm{T} \Delta \mathrm{S}$ and $\Delta \mathrm{G}$ (all in $\mathrm{kcal} / \mathrm{mol}$ ) are white, grey and black bars, respectively. $\Delta \mathrm{H}$ and $-\mathrm{T} \Delta \mathrm{S}$ numerical data are retrieved from GTT curves (SI.5), except for ${ }^{E c} \mathrm{M} 2$ and ${ }^{E c} \mathrm{G} 2$ (SI.6).

A similar approach aiming at defining the specific contributions of the same residues in the $B s$ context was hardly feasible as the large variations in thermodynamic data obtained with ${ }^{B s} \mathrm{SC}$ (Figure 1 and 4, SI.6) preclude one to retrieve any reliable conclusion on the contribution of the $\mathrm{P} / \mathrm{S}$ and $\mathrm{L} / \mathrm{M}$ residues in this context. Nevertheless, the thermodynamic profiles obtained with ${ }^{B s G 1} \mathrm{SC}$ and ${ }^{B s \mathrm{G} 2} \mathrm{SC}$ provide information on the contribution of the 
exchanged residue (Figure SI.12 B). As for the $\mathrm{S}_{346}$ residue in the $E c$ context, the $\mathrm{P}_{357}$ residue does not seems to contribute to the $\mathbf{P}_{7}$ interaction as indicated by the similarity of profiles observed with ${ }^{B s w t} \mathrm{SC}$ and ${ }^{B s G 1} \mathrm{SC}$ (Figure SI.12 B). On the contrary, the profiles obtained for the ${ }^{B s \mathrm{G} 2} \mathrm{SC} / \mathbf{P}_{7}$ interaction reveal that the $\mathrm{L}$ residue, as observed for the $\mathrm{M}_{362}$ residue in the $E c$ context, occupies a strategic position to impede the efficient interaction of $\mathbf{P}_{7}$ with ${ }^{B s w t} \mathrm{SC}$, as indicated by the fact that the $\mathrm{L}_{373} \mathrm{G}$ mutation restores an interaction profile similar to that observed for ${ }^{E c} \mathrm{SC}$ (Figure SI.12B). Indeed, the $\Delta \mathrm{Cp}$ value calculated for the ${ }^{{ }^{s} \mathrm{G} 2} \mathrm{SC} / \mathbf{P}_{\mathbf{7}}$ interaction is $-226 \mathrm{cal} / \mathrm{mol} / \mathrm{deg}$, equivalent to that measured with ${ }^{E c w t} \mathrm{SC}$.

\section{Specific contribution of the binding pocket to the $\mathbf{P}_{7}$ interaction.}

Beside these strategic positions, the whole pocket largely contributes to an efficient ligand binding, as revealed by the thermodynamic profiles obtained with G1 or G2 mutants (SI.12). In the $E c$ context, the pocket-specific thermodynamic profiles are only slightly modulated by the $\mathrm{S}_{346} \mathrm{G}$ or $\mathrm{M}_{362} \mathrm{G}$ mutation (Figure SI.12 A), while in the $B s$ context, the profiles obtained with G1 and G2 are very different (Figure SI.12 B). The G1 profile characterizes a weak interaction similar to that observed with ${ }^{\text {sswt }} \mathrm{SC}$. In contrast, the G2 profile, similar to those observed for the $E c$ context, reveals that the $B s$ pocket environment is also suitable for peptide binding, provided the $\mathrm{L}_{373}$ side chain is removed. This observation confirms the strategic position of the $B s_{373}$ (or $E c_{362}$ ) residue for the control of peptide interaction and the deleterious effect of $\mathrm{L}$ for $\mathbf{P}_{7}$ binding. However, as indicated by the $\mathrm{K}_{\mathrm{D}}$ values (SI.6), $\mathbf{P}_{7}$ interaction with ${ }^{B s \mathrm{G} 2} \mathrm{SC}$ remains weaker than with ${ }^{E c \mathrm{G} 2} \mathrm{SC}$ (SI.12). Moreover, the introduction of a $\mathrm{M}_{373}$ residue $\left({ }^{B s \mathrm{M} 2} \mathrm{SC}\right)$ fails to restore an interaction as strong as that observed in the Ec context (Figure 4 and SI.11), which may suggest that the side chain of this $\mathrm{M}$ residue is not adapted to the $B s$ pocket environment and that subtle pocket residue to residue interactions determine an optimal ligand interaction ${ }^{18}$.

In conclusion, thermodynamic analyses reveal that, for both $E c$ and $B s$ contexts, the same strategic position, corresponding to $E c \mathrm{M}_{362}$ or $B s \mathrm{~L}_{373}$, controls the efficient interaction of the peptide with the SC binding pocket. Residues at position corresponding to $E c S_{346}$ ( or $\left.B s \mathrm{P}_{357}\right)$ are not actively contributing to the binding. Finally, both pockets contribute to the interaction but with different efficiency. 


\section{Mode of peptide interaction as deduced from the $\Delta \mathrm{Cp}$ analysis.}

$\triangle \mathrm{Cp}$ analysis provides insights into the peptide mode of interaction with SC. It has been previously shown that a $\Delta \mathrm{Cp} \neq 0$ is partly linked to a variation in the hydration pattern and to a variation in the solvent accessible surface area (ASA) of the protein ${ }^{34}$. A $\triangle \mathrm{Cp}^{\text {calc }}$ value can be retrieved by measuring the ASA variation from the crystal structure of the ${ }^{\text {Ecwt }}{ }^{\mathrm{SC}} / \mathbf{P}_{7}$ complex (SI.9), as compared to the structure of the peptide free ${ }^{\text {Ecwt }} \mathrm{SC}$ (PDB 1OK7 chain A). This approach characterizes the $\Delta \mathrm{Cp}$ value resulting from the burying of amino acid residues upon peptide binding and is calculated using the empiric formula: $\Delta \mathrm{Cp}^{\text {calc }}=0.27$ $\Delta \mathrm{A}_{\text {aromatic }}+0.40 \Delta \mathrm{A}_{\text {nonaromatic }}{ }^{35}$. We also took into account the specific contribution of the free $\mathbf{P}_{7}$ by considering that the residues $\mathrm{Q}, \mathrm{L}$ and $\mathrm{F}$ were fully buried and Cha, which stacks on the platform \{Wolff, 2011 \#60\} was only 50\% hidden after binding. As indicated by the crystal structures, the D residue, which points toward the solvent, does not contribute to the interaction. Accessible surfaces area values for each $\mathbf{P 7}$ residue were determined according to $\{$ Lins, $2003 \# 122\}$. A value of $-276 \mathrm{cal} / \mathrm{mole} / \mathrm{deg}$ is calculated for ${ }^{E c w t} \mathrm{SC} / \mathbf{P}_{7}$ which is close to the $\triangle \mathrm{Cp}^{\text {ITC }}(-213 \mathrm{cal} / \mathrm{mol} / \mathrm{deg})$ considering the approximations on $\mathbf{P}_{\mathbf{7}}$. Similar close values are obtained for ${ }^{E c \mathrm{M} 1} \mathrm{SC} / \mathbf{P}_{7}\left(\triangle \mathrm{Cp}{ }^{\mathrm{ITC}}=-240 \mathrm{cal} / \mathrm{mole} / \mathrm{deg}\right.$ and $\left.\Delta \mathrm{Cp}^{\text {calc }}=-281 \mathrm{cal} / \mathrm{mole} / \mathrm{deg}\right)$.

In absence of any ${ }^{B s} \mathrm{SC} / \mathbf{P}_{7}$ complex structure, such information is not available for the $B s$ context. However, the profiles obtained with ${ }^{B s \mathrm{G} 2} \mathrm{SC}$ (SI.12 B) yields a $\Delta \mathrm{Cp}$ value of -226 $\mathrm{cal} / \mathrm{mol} / \mathrm{deg}$, very close to that measured with ${ }^{E c w t} \mathrm{SC}$. It suggests that this mutated pocket binds $\mathbf{P}_{\mathbf{7}}$ according to an induced-fit process and that the low $\Delta \mathrm{Cp}$ values calculated for ${ }^{B s w t} \mathrm{SC}$ and ${ }^{B s \mathrm{M} 1} \mathrm{SC}$ is more indicative of a weak interaction, due to the presence of the $\mathrm{L}$ residue, than of a different binding mode. Interestingly, the $\Delta \mathrm{Cp}$ value measured for ${ }^{B s \mathrm{M} 2} \mathrm{SC}(-42$ $\mathrm{cal} / \mathrm{mole} / \mathrm{deg}$ ) remains weak, despite the $\mathrm{L}_{373} \mathrm{M}$ mutation. Only for the double mutant ${ }^{B s \mathrm{M} 3} \mathrm{SC}$ is the $\Delta \mathrm{Cp}$ value $(-269 \mathrm{cal} / \mathrm{mole} / \mathrm{deg})$ in the range of that measured for ${ }^{B s G 2} \mathrm{SC}$. This may reflect the fact that, in contrast to $\mathrm{G}_{373}$, introducing a single $\mathrm{M}_{373}$ residue in the ${ }^{B s} \mathrm{SC}$ pocket does not trigger a large structural change, presumably because of some steric hindrance between the $\mathrm{M}_{373}$ side chain and the $\mathrm{P}_{357}$ residue (or others). Only the double mutant ${ }^{B s \mathrm{M} 3} \mathrm{SC}$ allows this structural change, as indicated by the corresponding $\Delta \mathrm{Cp}$ value, because the $S_{357}$ and $\mathrm{M}_{373}$ side chains move along, as observed in ${ }^{\mathrm{Ecwt}} \mathrm{SC}$. This observation reveals that a subtle network of residue to residue interactions operate specifically in each pocket, as we noted before $^{18}$, to ensure an optimal binding process. 


\section{Structure analysis of mutant $\mathrm{SC} / \mathrm{P}_{7}$ complexes.}

We solved the structures of different complexes, namely ${ }^{E c w t} \mathrm{SC} / \mathbf{P}_{7}$ (PDB ID: 6FVL), ${ }^{E c \mathrm{M} 1} \mathrm{SC} / \mathbf{P}_{7}$ (PDB ID: $6 \mathrm{FVM}$ ), ${ }^{M t \mathrm{wt}} \mathrm{SC} / \mathbf{P}_{7}$ (PDB ID: $6 \mathrm{FVN}$ ) and ${ }^{\mathrm{M} \mathrm{M} 1} \mathrm{SC} / \mathbf{P}_{7}$ (PDB ID: 6FVO) (SI.9). Until now, no structure of a SC/P $\mathbf{P}_{7}$ complex has been obtained using ${ }^{E c M 2} \mathrm{SC},{ }^{E c M 3} \mathrm{SC}$ or any ${ }^{B s}$ SC. Although crystals were obtained with these SC, no density corresponding to the peptide was observed in the electron density map. This observation reflects the weak peptide interaction, in agreement with thermodynamic and biochemical data, and suggests that $\mathbf{P}_{7}$ is mobile in these specific complexes, or that the crystallization process has selected the peptidefree SC. The overlay of several complexes structures is presented in SI.13. ${ }^{E c w t} \mathrm{Sc} / \mathbf{P}_{7}$ and ${ }^{E c \mathrm{M} 1} \mathrm{SC} / \mathbf{P}_{7}$ complexes align nicely, yielding an rmsd $=0.37 \AA$ over $327 \mathrm{C}_{\alpha}$ atoms (Figure SI.13 A). ${ }^{M t \mathrm{wt}} \mathrm{SC} / \mathbf{P}_{7}$ and ${ }^{\mathrm{Mt} \mathrm{M} 1} \mathrm{SC} / \mathbf{P}_{7}$ complexes also superimpose correctly, with an $\mathrm{rmsd}=0.89$ $\AA$ over $330 \mathrm{C}_{\alpha}$ atoms (Figure SI.13 C). Not surprisingly, ${ }^{E c w t} \mathrm{SC} / \mathbf{P}_{7}$ and ${ }^{M t w t} \mathrm{SC} / \mathbf{P}_{7}$ do not readily superimpose as indicated by an averaged $\mathrm{rmsd}=1.9 \AA$ over $280 \mathrm{C} \alpha$ atoms (Figure SI.13 B). Nevertheless, the two $\mathbf{P}_{7}$ peptides superimpose correctly. In all cases, we observed a full overlap of the ${ }^{E c w t} S_{346}$ and ${ }^{E c w t} \mathrm{M}_{362}$ or their corresponding residues in ${ }^{M \text { twt }} \mathrm{SC}$, with their cognate residues in the M1 mutant SC. This indicates that the conversion of this residue (from $\mathrm{S}$ to $\mathrm{P}$, or the opposite) does not alter the pocket conformation, in agreement with the ITC and biochemical data for the $E c$ replicative system (SI.11A and Figure 11 below).

\section{Kinetics analysis of the P7 binding onto SC.}

The treatment of the ITC injection curves by the kinITC program ${ }^{20}{ }^{32}$ provides the kinetic rate constants that govern the peptide interaction (Figure SI.14 A and B). Figure 6 shows the Arrhenius plots for the association and dissociation constants obtained at different temperatures for the interaction of $\mathbf{P}_{7}$ with ${ }^{E c w t} S C$ and ${ }^{E c \mathrm{M} 1} \mathrm{SC}$. No kinetic information could be obtained, neither for ${ }^{E c \mathrm{M} 2} \mathrm{SC} / \mathbf{P}_{7}$ and ${ }^{E c \mathrm{M} 3} \mathrm{SC} / \mathbf{P}_{7}$ complexes formation (SI.14 C and D), nor for ${ }^{B s w t} \mathrm{SC} / \mathbf{P}_{7}$ and ${ }^{M t w t} \mathrm{SC} / \mathbf{P}_{7}$ (data not shown), due to too weak signals.

The Arrhenius plots describing the ${ }^{E c} \mathrm{SC} / \mathbf{P}_{7}$ interaction (Figure 6) reveal a significant difference between the two complexes: an unusual negative $\Delta \mathrm{H}^{\ddagger}$ on is observed for the ${ }^{E c \mathrm{M} 1} \mathrm{SC} / \mathbf{P}_{7}$ complex formation because the $\mathrm{ON}$-rate decreases upon temperature increase. This can be interpreted in the frame of a two-step kinetic model, which was described in great 
details in two seminal papers on DNA helix formation. A two steps process has also been proposed previously for the ligand-SC system. According to this model, an initial but labile binding of $\mathbf{P}_{7}$ by one of its two anchors, the $\mathrm{N}$-ter $\mathrm{Q}$ residue or the $\mathrm{C}$-ter LF region, is followed by a fast step, conditioned by the first one, and corresponding to the full binding of the peptide into the SC pocket. Therefore, the observed $k_{\text {on }}$ is a global rate constant for the two successive steps, which explains that the global $\Delta \mathrm{H}_{\text {on }}^{\ddagger}$ may be negative. A smaller effect of the $\mathrm{S}_{346} \mathrm{P}$ mutation is also observed for the $\Delta \mathrm{H}^{\ddagger}$ off which is reduced four times with ${ }^{E c \mathrm{M} 1} \mathrm{SC}$ as compared to ${ }^{E c w t} \mathrm{SC}$. All together, these effects suggest that the ${ }^{E c w t} \mathrm{SC} / \mathbf{P}_{7}$ interaction proceeds through an induced-fit mechanism, in agreement with the $\Delta \mathrm{Cp}$ analysis, and that the mutation affects the binding-induced dynamics of the pocket but not the overall efficiency of binding, as indicated by the similar thermodynamic data obtained with ${ }^{E c w t} \mathrm{SC}$ and ${ }^{E c \mathrm{M} 1} \mathrm{SC}$ (SI.6).
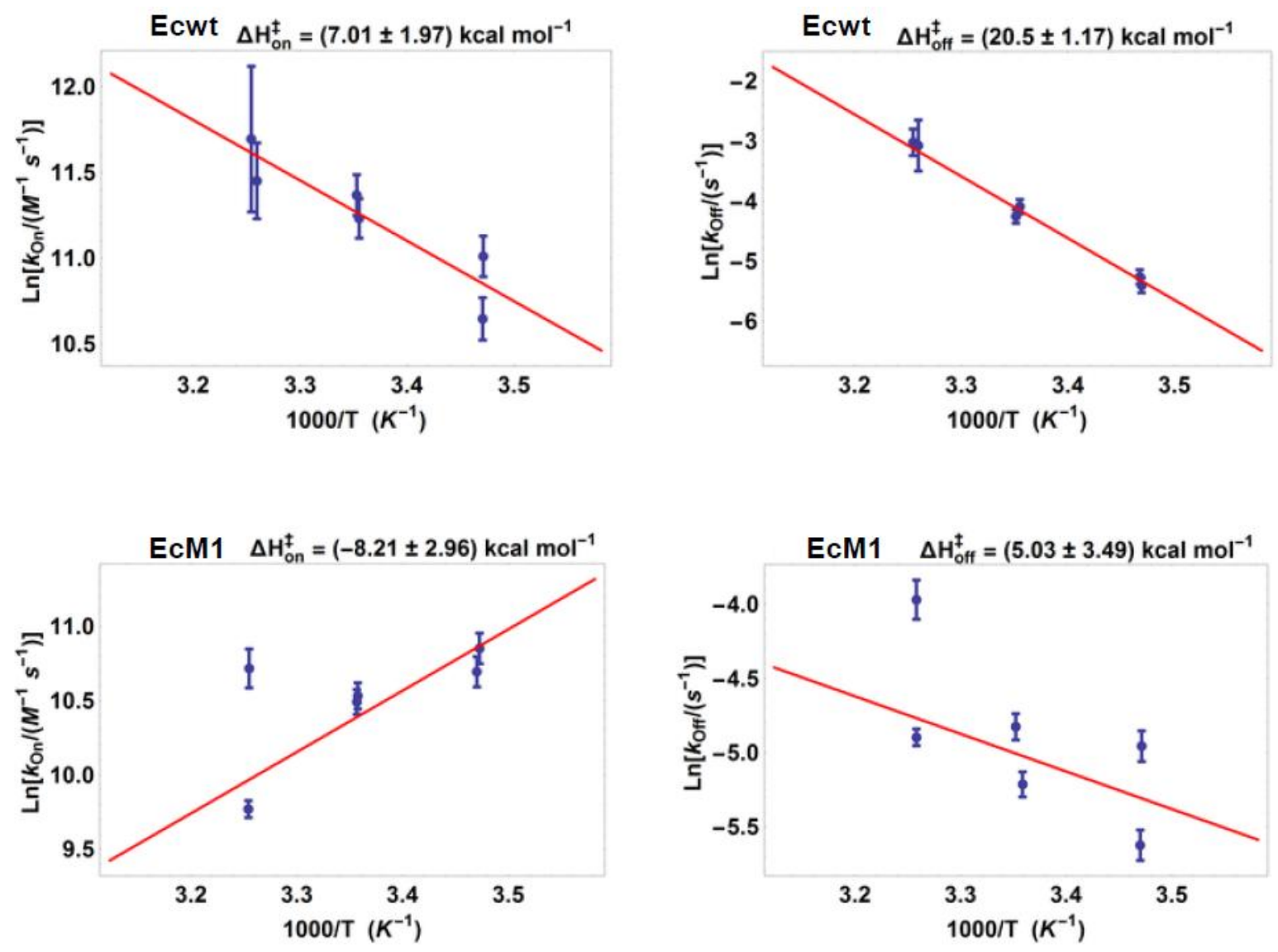
Figure 6: Arrhenius plots for the association and dissociation constants of ${ }^{E c w t} \mathrm{SC} / \mathbf{P}_{7}$ and ${ }^{E c \mathrm{M} 1} \mathrm{SC} / \mathbf{P}_{7}$ complexes. $\mathrm{k}_{\mathrm{on}}$ and $\mathrm{k}_{\text {off }}$ values measured for the ${ }^{E c w t} \mathrm{SC} / \mathbf{P}_{7}$ interaction are 3.4, 5.4 and 7.1 $10^{4} \mathrm{M}^{-1} . \mathrm{s}^{-1}$ and $4.8,15$ and $4710^{-3} \mathrm{~s}^{-1}$ at 15,25 and $34^{\circ} \mathrm{C}$, respectively. Values measured for the ${ }^{E c \mathrm{M} 1} \mathrm{SC} / \mathbf{P}_{7}$ interaction are $3.2,2.4$ and $2.110^{4} \mathrm{M}^{-1} \cdot \mathrm{s}^{-1}$ and 5.3, 6.7 and $1310^{-3} \mathrm{~s}^{-1}$.

\section{Molecular modeling studies.}

Molecular dynamics simulations were performed to elucidate how the nature of residues $E c \mathrm{M} / \mathrm{L}_{362}$ and $B s \mathrm{~L} / \mathrm{M}_{373}$ modulate the ligand interaction, as indicated by the ITC analyses. Table 3 compares the results of ITC-derived experimental and calculated $\Delta \Delta \mathrm{G}$ values. The simulation data are in good agreement with the experimental values and reveal that the $E c \mathrm{~L}_{362}$ residue is highly detrimental to the interaction while the $B s \mathrm{M}_{373}$ residue slightly favors the complex formation, in full agreement with our ITC analyses. The simulated structures of the different complexes $\left({ }^{B s w t} \mathrm{SC} / \mathbf{P}_{7}\right.$ and ${ }^{E c M 2} \mathrm{SC} / \mathbf{P}_{7}$ on one hand and ${ }^{E c w t} \mathrm{SC} / \mathbf{P}_{7}$ and ${ }^{B s M 2} \mathrm{SC} / \mathbf{P}_{\mathbf{7}}$ on the other hand) were superimposed (SI.15). In both cases, the peptides are nicely aligned (rmsd $\left(\mathrm{C}_{\alpha}\right)=0.38 \AA$ ), while the two SC chains present a looser alignement ( $\mathrm{rmsd}=$ $1.33 \AA$ over 305 atoms). Nevertheless, the superimposition reveals that in ${ }^{E c \mathrm{M} 2} \mathrm{SC}$ and ${ }^{B s w t} \mathrm{SC}$, the $\mathrm{L}_{362 / 373}$ residue positions immediately below the peptide's third residue (SI.15 A). This position blocks the path where the peptide can lie and results in a poor interaction, as observed by ITC for ${ }^{E c \mathrm{M} 2} \mathrm{SC}$ and ${ }^{B s w t} \mathrm{SC}$. In contrast, the $\mathrm{M}_{373}$ residue of ${ }^{\mathrm{BsM} 2} \mathrm{SC}$ adopts

\begin{tabular}{|c|c|c|}
\hline Data for peptide binding & $\Delta \Delta \mathrm{G}^{E c \mathrm{M} 2} \mathrm{SC}$ vs ${ }^{E c \mathrm{wt}} \mathrm{SC}$ & $\Delta \Delta \mathrm{G}^{B s \mathrm{M} 2} \mathrm{SC}$ vs ${ }^{B s \mathrm{wt}} \mathrm{SC}$ \\
\hline Experimental (ITC) & $2,8 \pm 1.1$ & $-0,3 \pm 0.5$ \\
\hline Calculated & $3,7 \pm 0,7$ & $-0,4 \pm 0,04$ \\
\hline
\end{tabular}

Table 3: Comparison of calculated and experimental $\Delta \Delta \mathrm{G}$ values. $\Delta \Delta \mathrm{G}(\mathrm{kcal} / \mathrm{mole})$ results from the comparison between $\Delta \mathrm{G}^{\mathrm{M} 2} \mathrm{SC}$ and $\Delta \mathrm{G}^{\mathrm{wt}} \mathrm{SC}$ (namely, $\Delta \mathrm{G}{ }^{\mathrm{M} 2} \mathrm{SC}-\Delta \mathrm{G}{ }^{\mathrm{wt}} \mathrm{SC}$ ) at $25^{\circ} \mathrm{C}$. When positive, binding to mutant is less favorable. In ${ }^{E c} \mathrm{SC}, \mathrm{M} 2$ corresponds to a $\mathrm{M}_{362} \mathrm{~L}$ mutation (Table 1). In ${ }^{B s} \mathrm{SC}, \mathrm{M} 2$ corresponds to a $\mathrm{L}_{373} \mathrm{M}$ mutation (Table 1).

a position similar to the $\mathrm{M}_{362}$ position in ${ }^{E c w t} \mathrm{SC}$ (SI.15 B), i.e a shift of its side chain that clear the way for the peptide to lie within the resulting groove, thus allowing an improved interaction. 


\section{Biochemical analysis of the various SC activities.}

We used a primer elongation assay to analyze the biochemical properties of the various ${ }^{E c} \mathrm{SC}$ and ${ }^{B s} \mathrm{SC}$ to promote SC dependent polymerization by in vitro reconstituted cognate and non-cognate replicative DNA polymerase complexes. In this assay, the interaction between the replicase and the clamps is mediated by the polymerase specific peptide, namely QADMF for the E. coli polIII holoenzyme ${ }^{36}$ and QLSLF for the B. subtilis PolC $^{16}$. The ability of $\mathbf{P}_{7}$ to interact with these various SC in this biochemical tests is evaluated in competition assays.

As shown in Figure 7, both ${ }^{E c w t} \mathrm{SC}$ and ${ }^{B s w t} \mathrm{SC}$ associate with their cognate in vitro reconstituted E. coli $(\mathrm{EcP})$ and B. subtilis (BsP) DNA polymerases to promote a SC dependent primer elongation. The reaction is concentration dependent and saturation is reached at equimolar concentrations of SC and polymerases (100 fmole/reaction). The elongation profiles show distinct bands of arrest specific for each type of polymerase, which may result from a different sensitivity of each complex for DNA sequences or secondary structures. Neither the $E$. coli nor the $B$. subtilis replicative complexes (comprised of at least the DNA polymerase catalytic subunit and the SC loading complex) are able to form productive complexes with the non cognate SC (SI.16), as previously observed by others when E. coli (Gram-) and S. pyogenes (Gram+) replicative machineries were analyzed ${ }^{37}$. This underlines the specificity of interaction between the partners, mediated by the specific peptides but also others polymerase-SC contacts such as described for Ec PolIV ${ }^{17}$ \{Beuning, $2006 \# 123\}$. 


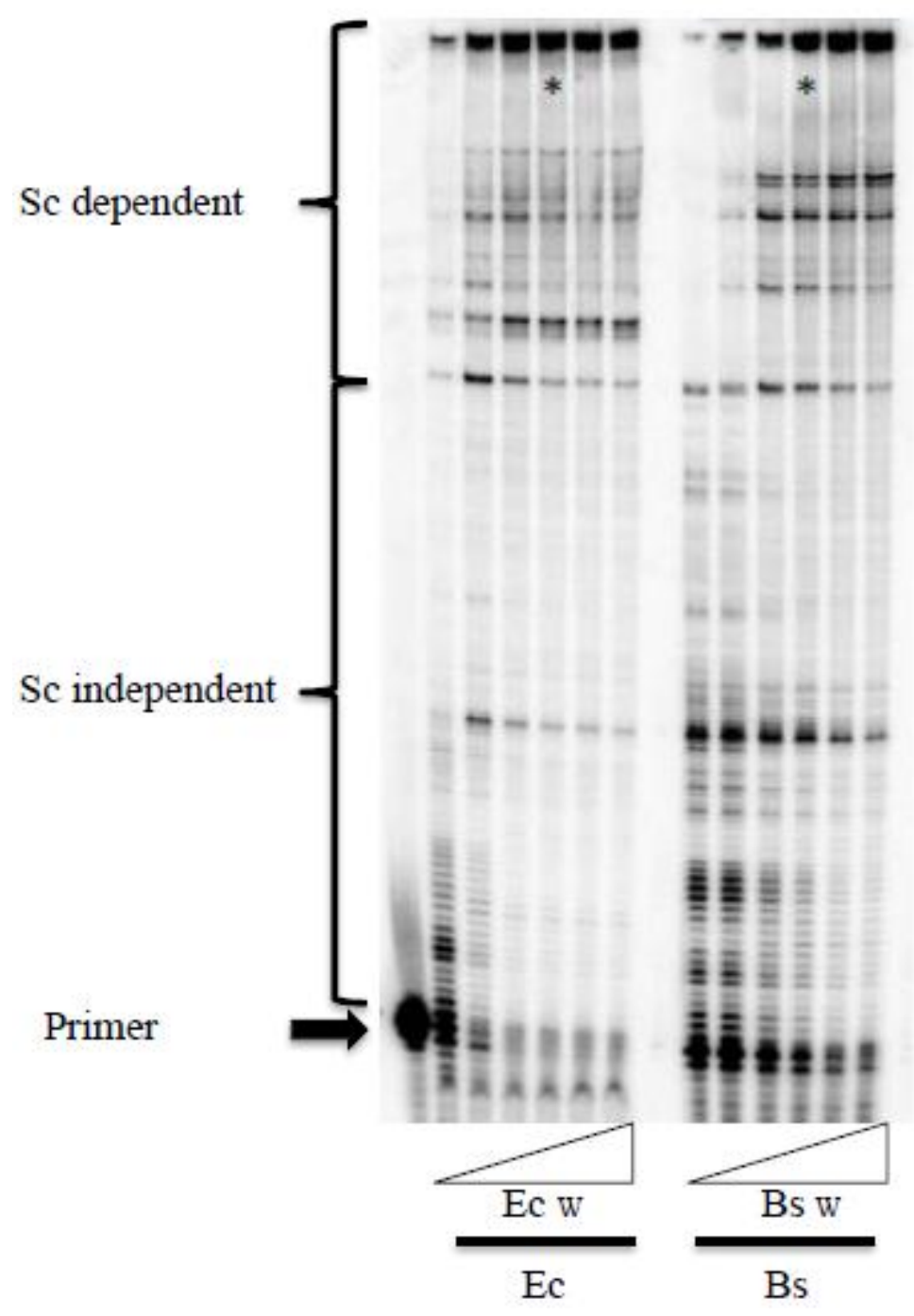

Figure 7 : Elongation profiles obtained with reconstituted $E$. coli and B. subtilis holoenzymes. The $E$. coli and B. subtilis polymerases (EcP or BsP, 100 fmoles) are supplemented with various amount of the cognate ${ }^{\mathrm{wt}} \mathrm{SC}$ (from 0 to 400 fmoles). The labeled lanes $(*)$ correspond to 100 fmoles ${ }^{\mathrm{wt}} \mathrm{SC}$. The primer position is indicated by the arrow.

Then we analyzed how EcP and BsP behave when associated with the different cognate mutant SC (Figure 8). Holoenzyme formed between EcP and ${ }^{E c M l}$ SC (Figure 8, lane 4) displays the same primer elongation profile as that observed using ${ }^{E c w t} \mathrm{SC}$ (Figure 8, lane 3). This indicates that the natural EcP peptide interaction is not altered by the $\mathrm{S}_{346} \mathrm{P}$ mutation, nor in terms of elongation efficiency, as indicated by the equal bands intensities in lanes 3 and 4 , nor in terms of specificity as indicated by their similar elongation profiles. This result is in agreement with the $\mathbf{P}_{\mathbf{7}}$ interaction data obtained in ITC experiments (Figure SI. 8 A and S.I $11 \mathrm{~A}$ ). In contrast, holoenzymes formed by association of EcP with ${ }^{E c M 2} \mathrm{SC}$ or ${ }^{E c M 3} \mathrm{SC}$ (Figure $\mathbf{8}$, lanes 5 and 6) present a profile different from that observed for the natural holoenzyme, 
which can be accounted for by a decrease in processivity and/or modifications of polymeraseSC interaction dynamics. This is in agreement with the ITC data and indicates that, regardless of the peptide, the $\mathrm{M}_{362} \mathrm{~L}$ mutation is deleterious to the interaction. The combination of both mutations $\left({ }^{E c M 3} \mathrm{SC}\right.$, lane 6) shows a synergistic effect, as revealed by the decrease in full length band intensity in lane 6 as compared to lane 5. Surprisingly enough, these profiles, and particularly that obtained with ${ }^{E c M 3} \mathrm{SC}$, are very similar to that obtained with the natural $\mathrm{BsP}$ holoenzyme (Figure 8, lane 8).

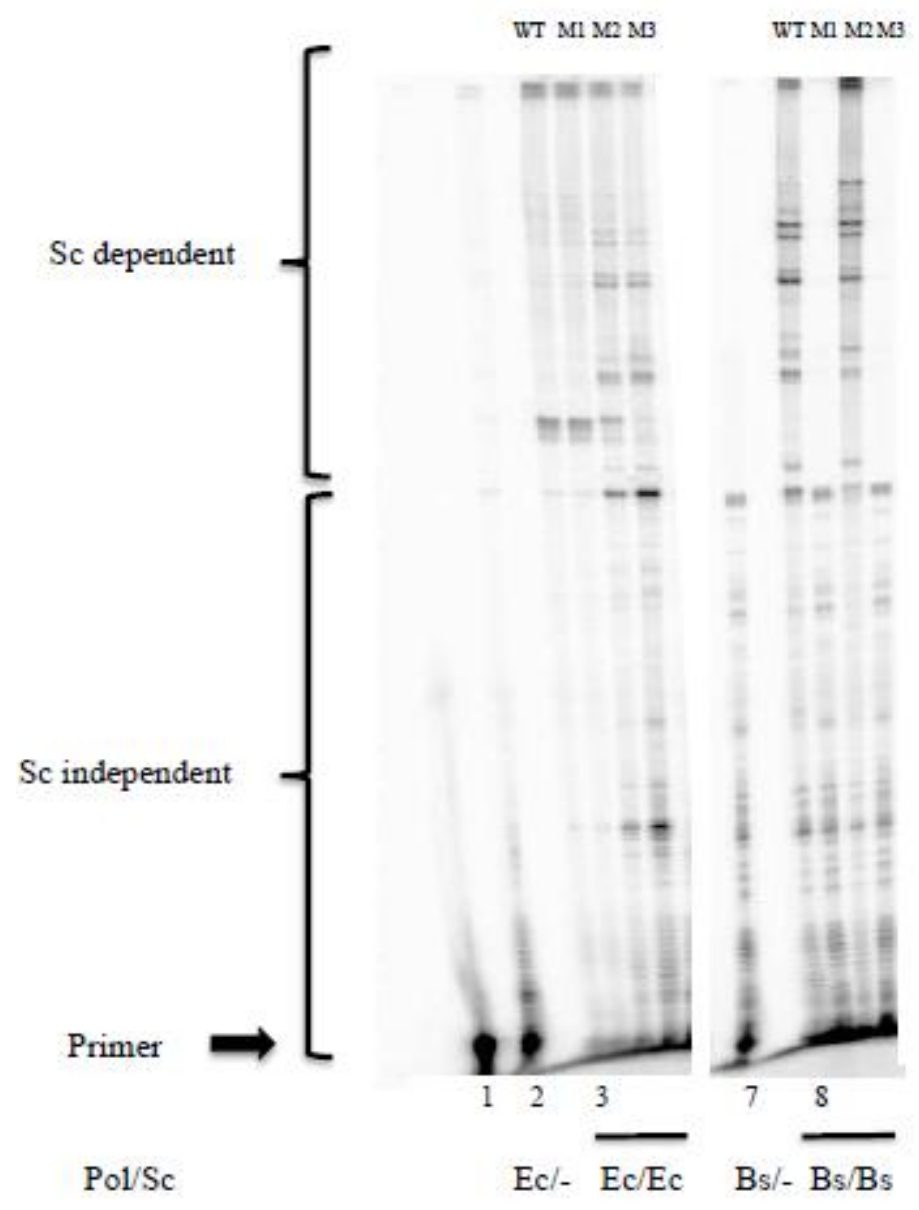

Figure 8: Elongation assays with the different ${ }^{E c} \mathrm{Sc}$ and ${ }^{B s} \mathrm{Sc}$. EcP or BsP reconstituted polymerases (100 fmoles) were each tested with the various cognate SC (lanes 3 to 6 and lanes 8 to 11 for Ec and Bs polymerases, respectively) (100 fmoles) (Table 1). The primer position is indicated by the arrow (lane 1). Lanes 2 and 7 display the activity of $E c$ and $B s$ polymerases in absence of the cognate SC.

We observed that only ${ }^{B S M 2} \mathrm{SC}$ associates productively with $\mathrm{BsP}$ and yields a similar pattern of elongation as the natural BsP holoenzyme (Figure 8, lane 10), while nor ${ }^{B s M l} \mathrm{SC}$ neither ${ }^{B s M 3} \mathrm{SC}$ form a productive complex (Figure 8, lane 9 and 11). In this Gram+ context, 
the $\mathrm{P}_{357} \mathrm{~S}$ mutation appears to be highly deleterious to the polymerase-SC interaction, as opposed to what is observed with the ${ }^{E c} \mathrm{SC}$, while the $\mathrm{L}_{373} \mathrm{M}$ mutation is harmless and even favorable to the interaction, as indicated by the increased band intensities of the full length products (lane 10). The lack of elongation with ${ }^{B s M 3} \mathrm{SC}$ is in contradiction with ITC data showing that the combination of the two mutations in ${ }^{B s M 3} \mathrm{SC}$ improves the $\mathbf{P}_{\mathbf{7}}$ interaction as compared to ${ }^{B s M l} \mathrm{SC} / \mathbf{P}_{\mathbf{7}}$ or ${ }^{B s M 2} \mathrm{SC} / \mathbf{P}_{\mathbf{7}}$ interactions (Figure 4). In the elongation assay, the effect of both mutations is not cumulative but rather reflects the effect of the $\mathrm{P}_{357} \mathrm{~S}$ mutation alone. These differences between the two approaches reveals that, in the Bs context, the $S_{357}$ residue blocks the interaction of the PolC polymerase natural peptide with ${ }^{\mathrm{Bs}} \mathrm{SC}$, but not that of $\mathbf{P}_{7}$. Alternatively, the $B s \mathrm{P}_{357}$ position could have some unknown specific contribution to the whole polymerase function. This effect is not observed in the $E c$ context and could thus reveal this position as a specific marker for Gram+ SC/polymerase interaction. Finally, as observed for both natural SC, none of the mutants SC form a productive heterologous complex with their non cognate polymerase (data not shown).

To make sure that the effects observed with BsP reflect the polymerase activity and not the SC loading process, we performed the same assay using a linear template (SI.17). SC dependent elongation products are detected with the ${ }^{B s w t} \mathrm{SC}$ and ${ }^{B s \mathrm{M} 2} \mathrm{SC}$, as observed when using circular templates, but none with ${ }^{B s \mathrm{M} 1} \mathrm{SC}$, ruling out any defect in the SC loading process. Noteworthy, in this assay with linear templates, we observed ${ }^{B s \mathrm{M} 3} \mathrm{SC}$ dependent products, as opposed to what we obtained using circular DNA (Figure 8, lane 11). This suggests that the observed increased elongation activity brought by the $\mathrm{L}_{373} \mathrm{M}$ mutation compensate the deleterious effect of the $\mathrm{P}_{357} \mathrm{~S}$ mutation for what concerns the polymerase interaction, but not the SC loading process. Elucidation of this point will require the study of the respective natural peptides with these SC variants.

Then, we challenged the different reconstituted holoenzymes for their primer elongation activity with increasing concentrations of $\mathbf{P}_{\mathbf{7}}$. The elongation profiles are displayed in Figure 9, and the data are analyzed in Figure 10. In accordance with our previous observations in Figure 8 (lanes 3 and 4) showing that ${ }^{E c w t} \mathrm{SC}$ and ${ }^{E c M l} \mathrm{SC}$ are similarly efficient in driving EcP SC-dependent elongation, equal concentrations of $\mathbf{P}_{7}$, pre-incubated with ${ }^{E c w t} \mathrm{SC}$ or ${ }^{E c M l} \mathrm{SC}$, equally inhibit the SC dependent primer elongation activity of EcP, yielding a $\mathrm{IC}_{50}$ of $1.5 \mu \mathrm{M}$ (Figure $10 \mathrm{~A}, \mathrm{D}$ ). These values are close to our previous results yielding an $\mathrm{IC}_{50}$ of $2.8 \mu \mathrm{M}$ for the inhibition of EcP holoenzyme elongation by $\mathbf{P}_{7}{ }^{5}$. These 
experiments confirm that the $\mathrm{S}_{346} \mathrm{P}$ mutation has no, or a limited influence on the peptides binding, either the natural peptide (QADMF) or $\mathbf{P}_{7}$. We note a 4-fold difference between these biochemical results and those measured by ITC at $34^{\circ} \mathrm{C}$ (SI. 6), but both approaches describe the same trend despite their different sensitivity, as observed before ${ }^{5}$.
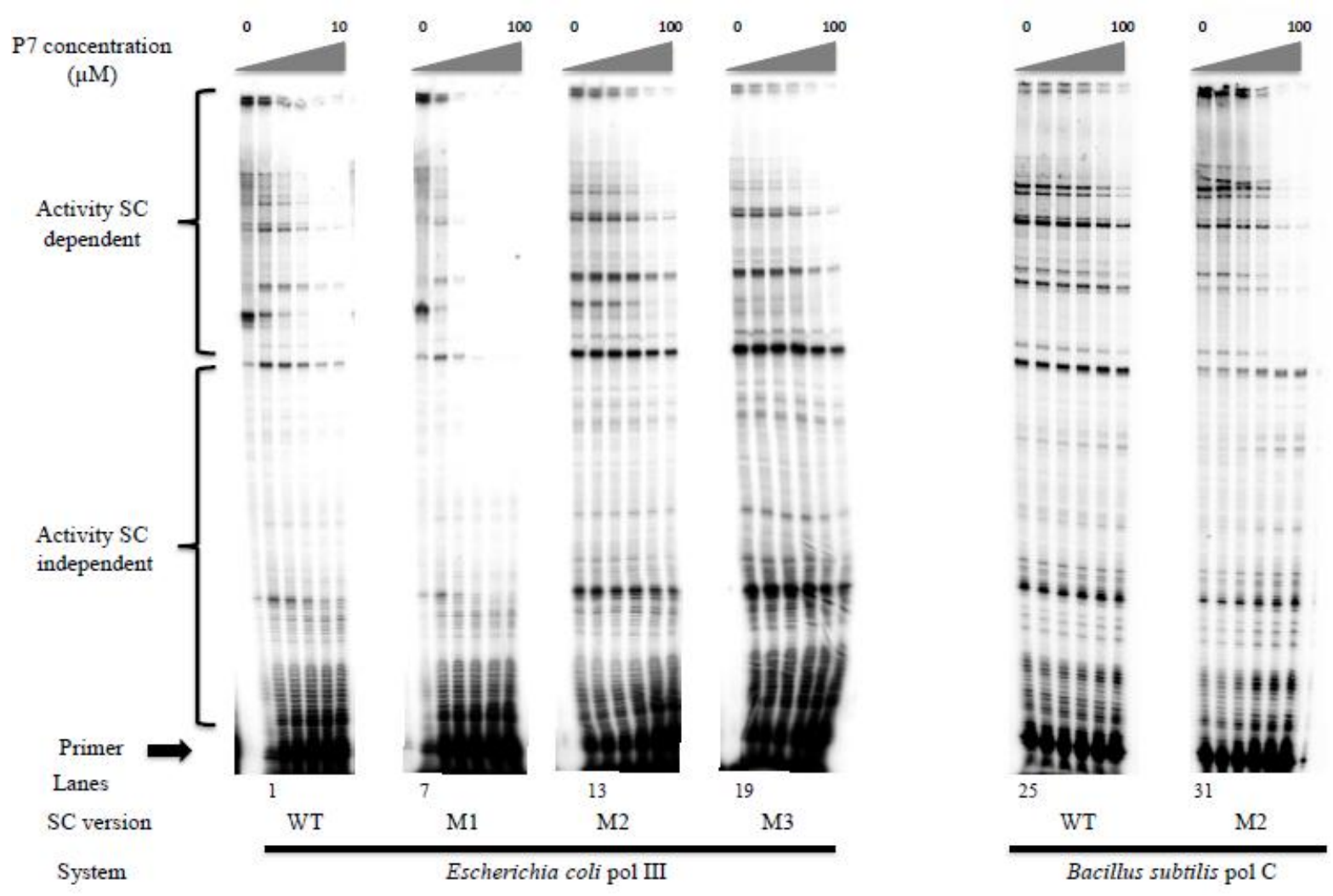

Figure 9 : Inhibition of primer elongation by $\mathbf{P}_{7}$. EcP and $\mathrm{BsP}$ are complemented with their cognate wt or mutants SC pre-incubated with increasing concentrations of $\mathbf{P 7}$ peptide $(0,1,2,4,8$ and $10 \mu \mathrm{M}$ for ${ }^{E c w t} \mathrm{SC}$ and $0,2,8,25$ and $75 \mu \mathrm{M}$ for all the other SC). Lanes 1 to 6: $\mathrm{EcP}_{-}{ }^{E c w t} \mathrm{SC}$. Lanes 7 to 12: $\mathrm{EcP}_{-}{ }^{E c M l} \mathrm{SC}$. Lanes 13 to 18: $\mathrm{EcP}^{-}{ }^{E c M 2} \mathrm{SC}$. Lanes 19 to 24: $\mathrm{EcP}_{-}{ }^{E c M 3} \mathrm{SC}$. Lanes 25 to 30: $\mathrm{BPP}_{-}{ }^{B s w} \mathrm{SC}$. Lanes 31 to 36: $\mathrm{BsP}_{-}^{B s M 2} \mathrm{SC}$.

The same approach using ${ }^{E c M 2} \mathrm{SC}$ or ${ }^{E c M 3} \mathrm{SC}$ yield a much higher $\mathrm{IC}_{50}$ value of $46 \mu \mathrm{M}$, indicating a much weaker interaction of these $\mathrm{SC}$ with $\mathbf{P}_{\mathbf{7}}$ (Figure $\left.10 \mathrm{~B}, \mathrm{D}\right)$, in agreement with our ITC data (SI.6). All the results from different analytical approaches indicate that for ${ }^{E c} \mathrm{SC}$, the introduction of a $\mathrm{S}_{346} \mathrm{P}$ mutation is innocuous, whereas the $\mathrm{M}_{362} \mathrm{~L}$ mutation is strongly deleterious. 
Finally, we challenged the natural BsP holoenzyme and its ${ }^{B s \mathrm{M} 2} \mathrm{SC}$ supplemented version by $\mathbf{P}_{\mathbf{7}}$ (Figure $\left.10 \mathrm{C}, \mathrm{D}\right)$. While the interaction of $\mathbf{P}_{7}$ with ${ }^{B s w t} \mathrm{SC}$ is weak $\left(\mathrm{IC}_{50}=68\right.$ $\mu \mathrm{M}$ ), in agreement with our ITC data (SI.2), a 5 fold $\left(\mathrm{IC}_{50}=14 \mu \mathrm{M}\right)$ improvement is measured by introduction of the $\mathrm{L}_{373} \mathrm{M}$ mutation in ${ }^{B s} \mathrm{SC}$, in good agreement with ITC and MD data.
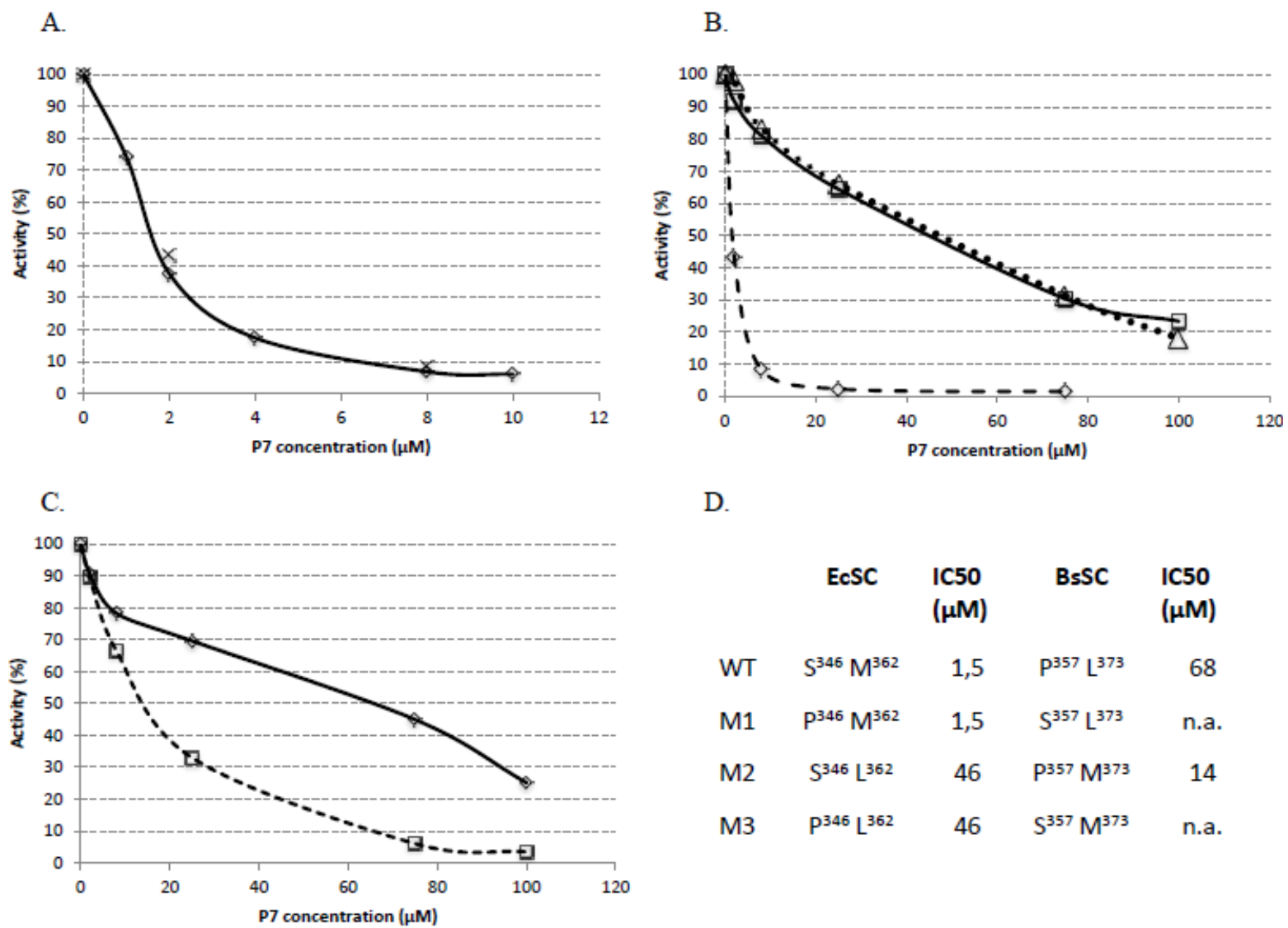

D.

$\begin{array}{ccccc}\text { EcSC } & \begin{array}{c}\text { IC50 } \\ (\mu M)\end{array} & \text { BsSC } & \begin{array}{r}\text { IC50 } \\ (\mu M)\end{array} \\ \text { WT } & S^{346} \mathrm{M}^{362} & 1,5 & \mathrm{P}^{357} \mathrm{~L}^{373} & 68 \\ \mathrm{M} 1 & \mathrm{P}^{346} \mathrm{M}^{362} & 1,5 & \mathrm{~S}^{357} \mathrm{~L}^{373} & \text { n.a. } \\ \mathrm{M} 2 & \mathrm{~S}^{346} \mathrm{~L}^{362} & 46 & \mathrm{P}^{357} \mathrm{M}^{373} & 14 \\ \mathrm{M} 3 & \mathrm{P}^{346} \mathrm{~L}^{362} & 46 & \mathrm{~S}^{357} \mathrm{M}^{373} & \text { n.a. }\end{array}$

Figure 10: Quantification of EcP and BsP holoenzymes inhibition by $\mathbf{P}_{7} \cdot{ }^{A}{ }^{E c w t} S C$ (diamonds); ${ }^{E c M l} \mathrm{SC}$ (crosses). B: ${ }^{E C M I} \mathrm{SC}$ (diamonds, dotted line); ${ }^{E c M 2} \mathrm{SC}$ (squares, black line); ${ }^{E c M 3} \mathrm{SC}$ (triangles, dotted line). C: ${ }^{B s w t} \mathrm{SC}$ (diamonds); ${ }^{B s M 2} \mathrm{SC}$ (squares, dotted line). D: Determination of IC50 from the curves in A, $\mathbf{B}$ and $\mathbf{C}$.

\section{CONCLUSION.}

The interaction of all DNA polymerases with the replicative processivity factor (or SC) is central for their activities and is mediated by a conserved peptide sequence which binds into a hydrophobic pocket located at the SC surface. In this piece of work, we analyzed the interaction of a reference peptide, $\mathbf{P}_{7}$, with natural and mutant SC from E. coli, B. subtilis and M. tuberculosis. In particular, we focused on the contribution of two residues of the ${ }^{E c} \mathrm{SC}$ binding pocket, namely $\mathrm{S}_{346}$ and $\mathrm{M}_{362}$, and their corresponding residues in ${ }^{B s} \mathrm{SC}, \mathrm{P}_{357}$ and $\mathrm{L}_{373}$. 
ITC experiments confirm the differential interaction of $\mathbf{P}_{7}$ with the different natural SC. Single mutant analyses identify a strategic position in the ${ }^{E c} \mathrm{SC}$ binding pocket: a single $\mathrm{M}_{362} \mathrm{~L}$ mutation is sufficient 1) to turn the thermodynamic profile of $\mathbf{P}_{7}$ interaction into that observed with ${ }^{B s w t}$ SC , 2) to inhibit the SC dependant activity of the Pol III holoenzyme and 3) to reduce the competitive inhibitory effect of $\mathbf{P}_{7}$ on this enzyme activity. Converesely, the $\mathrm{L}_{373} \mathrm{M}$ substitution in the ${ }^{B s} \mathrm{SC}$ pocket strongly modifies the thermodynamic profile which becomes almost similar to that observed in the natural Ec context. All these results are in line with molecular dynamics data indicating that, contrary to $\mathrm{M}$ residues that, in both $E c$ and $B s$ contexts, shift upon peptide interaction, $\mathrm{L}$ residues remain in place, immediately below the peptide, providing a structural rationale for the peptide binding inhibition in ${ }^{E c \mathrm{M} 2} \mathrm{SC}$ and in ${ }^{B s w t} \mathrm{SC}$. $\Delta \mathrm{Cp}$ analyses reveal that all binding pockets endow a large structural change upon peptide binding, suggesting that $\mathbf{P}_{7}$ interacts through an induced fit process ${ }^{33}$. In the case of ${ }^{B s} \mathrm{SC}$, this process is observed only with G2 and M3 mutants, because they lack the static $\mathrm{L}_{373}$ residue which blocks peptide interaction. This indicates that the weak $\Delta \mathrm{Cp}$ values calculated for ${ }^{B s \mathrm{wt}} \mathrm{SC},{ }^{E c \mathrm{M} 2} \mathrm{SC}$ and others, reveal a poor peptide binding and not necessarily a change in binding mode.

Thermodynamic analyses suggest that the nature of the $E c_{346}$ residue ( $\mathrm{S}$ or $\mathrm{P}$ ) is not as important for the binding as the $\mathrm{M}_{362}$ residue, as deduced from the closely similar thermodynamic profiles obtained with ${ }^{E c \mathrm{wt}} \mathrm{SC},{ }^{E c \mathrm{Gl}} \mathrm{SC}$ and ${ }^{E c \mathrm{Ml} 1} \mathrm{SC}$. However, kinetics analyses reveal that the $\mathrm{S}_{346} \mathrm{P}$ mutation strongly reduces the pocket dynamics. This suggests that the residue composition of each binding pocket is highly specific and has evolved to ensure an optimized binding process through a complex and specific network of interaction, as observed previously ${ }^{18}$. Another example is illustrated in the $B s$ context where biochemical analyses highlighted the $\mathrm{P}_{357}$ residue as a $B s$ specific strategic position for productive elongation. These data underline the interest of a multidisciplinary approach in defining the binding characteristics of each binding pocket and will help in the future design of SC targeting compounds, with either large spectrum or strain specific activities.

\section{AUTHORS INFORMATIONS}

Corresponding Author 
E-mail: d.burnouf@ibmc-cnrs.unistra.fr. phone: 33388417 002; fax: 33388602218

\section{Author Contributions}

+ These authors contributed equally.

\section{ACKNOWLEDGMENTS}

This work was supported by a grant IMMI n 2014014 funded by AstraZeneca and INSERM (I3M). X-ray data were collected at the Paul Scherrer Institut, Villigen, Switzerland through several SLS proposals for provision of synchrotron radiation beamtime, at beamline X06DA PXIII. We are grateful to Dr C. McHenry (U. of Colorado, Boulder, Co, USA) for the gift of replicative plasmids and proteins.

\section{ABBREVIATIONS}

ITC, Isothermal Titration Calorimetry; N-ter: N-terminal ; C-ter : C-terminal ; Ac: acetyl group; Cha: $\beta$-cyclohexyl-L-alanyl; (3,4-di-Cl)Phe : 3,4-dichloro-L-phenylalanyl.

\section{REFERENCES.}

1. WHO WHO report 2011: Global Tuberculosis Control; ISBN 978924156438 0; Geneva, 2011.

2. Lopez de Saro, F. J.; Georgescu, R. E.; Goodman, M. F.; O'Donnell, M., Competitive processivity-clamp usage by DNA polymerases during DNA replication and repair. Embo J 2003, 22, (23), 6408-6418.

3. Burnouf, D. Y.; Olieric, V.; Wagner, J.; Fujii, S.; Reinbolt, J.; Fuchs, R. P.; Dumas, P., Structural and biochemical analysis of sliding clamp/ligand interactions suggest a competition between replicative and translesion DNA polymerases. J Mol Biol 2004, 335, (5), 1187-1197.

4. Georgescu, R. E.; Yurieva, O.; Kim, S. S.; Kuriyan, J.; Kong, X. P.; O'Donnell, M., Structure of a small-molecule inhibitor of a DNA polymerase sliding clamp. Proc Natl Acad Sci U S A 2008, 105, (32), 11116-11121.

5. Wolff, P.; Olieric, V.; Briand, J. P.; Chaloin, O.; Dejaegere, A.; Dumas, P.; Ennifar, E.; Guichard, G.; Wagner, J.; Burnouf, D. Y., Structure-based design of short peptide ligands binding onto the E. coli processivity ring. J Med Chem 2011, 54, (13), 4627-4637.

6. Wijffels, G.; Johnson, W. M.; Oakley, A. J.; Turner, K.; Epa, V. C.; Briscoe, S. J.; Polley, M.; Liepa, A. J.; Hofmann, A.; Buchardt, J.; Christensen, C.; Prosselkov, P.; Dalrymple, B. P.; Alewood, P. F.; Jennings, P. A.; Dixon, N. E.; Winkler, D. A., Binding inhibitors of the bacterial sliding clamp by design. J Med Chem 2011, 54, (13), 4831-4838.

7. $\quad$ Kling, A.; Lukat, P.; Almeida, D. V.; Bauer, A.; Fontaine, E.; Sordello, S.; Zaburannyi, N.; Herrmann, J.; Wenzel, S. C.; Konig, C.; Ammerman, N. C.; Barrio, M. B.; Borchers, K.; BordonPallier, F.; Bronstrup, M.; Courtemanche, G.; Gerlitz, M.; Geslin, M.; Hammann, P.; Heinz, D. W.; Hoffmann, H.; Klieber, S.; Kohlmann, M.; Kurz, M.; Lair, C.; Matter, H.; Nuermberger, E.; Tyagi, S.; Fraisse, L.; Grosset, J. H.; Lagrange, S.; Muller, R., Antibiotics. Targeting DnaN for tuberculosis therapy using novel griselimycins. Science 2015, 348, (6239), 1106-1112.

8. Yin, Z.; Kelso, M. J.; Beck, J. L.; Oakley, A. J., Structural and thermodynamic dissection of linear motif recognition by the E. coli sliding clamp. J Med Chem 2013, 56, (21), 8665-8673. 
9. $\quad$ Yin, Z.; Whittell, L. R.; Wang, Y.; Jergic, S.; Liu, M.; Harry, E. J.; Dixon, N. E.; Beck, J. L.; Kelso, M. J.; Oakley, A. J., Discovery of Lead Compounds Targeting the Bacterial Sliding Clamp Using a Fragment-Based Approach. J Med Chem 2014.

10. Kong, X. P.; Onrust, R.; O'Donnell, M.; Kuriyan, J., Three-dimensional structure of the beta subunit of E. coli DNA polymerase III holoenzyme: a sliding DNA clamp. Cell 1992, 69, (3), 425437.

11. Fay, P. J.; Johanson, K. O.; McHenry, C. S.; Bambara, R. A., Size classes of products synthesized processively by DNA polymerase III and DNA polymerase III holoenzyme of Escherichia coli. J Biol Chem 1981, 256, (2), 976-983.

12. Wagner, J.; Fujii, S.; Gruz, P.; Nohmi, T.; Fuchs, R. P., The beta clamp targets DNA polymerase IV to DNA and strongly increases its processivity. EMBO Rep 2000, 1, (6), 484-488.

13. Becherel, O. J.; Fuchs, R. P.; Wagner, J., Pivotal role of the beta-clamp in translesion DNA synthesis and mutagenesis in E. coli cells. DNA Repair (Amst) 2002, 1, (9), 703-708.

14. Lenne-Samuel, N.; Wagner, J.; Etienne, H.; Fuchs, R. P., The processivity factor beta controls DNA polymerase IV traffic during spontaneous mutagenesis and translesion synthesis in vivo. EMBO Rep 2002, 3, (1), 45-49.

15. Lopez de Saro, F. J.; O'Donnell, M., Interaction of the beta sliding clamp with MutS, ligase, and DNA polymerase I. Proc Natl Acad Sci U S A 2001, 98, (15), 8376-8380.

16. Dalrymple, B. P.; Kongsuwan, K.; Wijffels, G.; Dixon, N. E.; Jennings, P. A., A universal protein-protein interaction motif in the eubacterial DNA replication and repair systems. Proc Natl Acad Sci U S A 2001, 98, (20), 11627-11632.

17. Bunting, K. A.; Roe, S. M.; Pearl, L. H., Structural basis for recruitment of translesion DNA polymerase Pol IV/DinB to the beta-clamp. Embo J 2003, 22, (21), 5883-5892.

18. Wolff, P.; Amal, I.; Olieric, V.; Chaloin, O.; Gygli, G.; Ennifar, E.; Lorber, B.; Guichard, G.; Wagner, J.; Dejaegere, A.; Burnouf, D. Y., Differential modes of peptide binding onto replicative sliding clamps from various bacterial origins. J Med Chem 2014, 57, (18), 7565-7576.

19. Yin, Z.; Whittell, L. R.; Wang, Y.; Jergic, S.; Ma, C.; Lewis, P. J.; Dixon, N. E.; Beck, J. L.; Kelso, M. J.; Oakley, A. J., Bacterial Sliding Clamp Inhibitors that Mimic the Sequential Binding Mechanism of Endogenous Linear Motifs. J Med Chem 2015, 58, (11), 4693-4702.

20. Burnouf, D.; Ennifar, E.; Guedich, S.; Puffer, B.; Hoffmann, G.; Bec, G.; Disdier, F.;

Baltzinger, M.; Dumas, P., kinITC: a new method for obtaining joint thermodynamic and kinetic data by isothermal titration calorimetry. J Am Chem Soc 2012, 134, (1), 559-565.

21. Waltersperger, S.; Olieric, V.; Pradervand, C.; Glettig, W.; Salathe, M.; Fuchs, M. R.; Curtin, A.; Wang, X.; Ebner, S.; Panepucci, E.; Weinert, T.; Schulze-Briese, C.; Wang, M., PRIGo: a new multi-axis goniometer for macromolecular crystallography. J Synchrotron Radiat 2015, 22, (4), 895900.

22. Vonrhein, C.; Flensburg, C.; Keller, P.; Sharff, A.; Smart, O.; Paciorek, W.; Womack, T.; Bricogne, G., Data processing and analysis with the autoPROC toolbox. Acta Crystallogr D Biol Crystallogr 2011, 67, (Pt 4), 293-302.

23. Tickle, I.; Flensburg, C.; Keller, P.; Paciorek, W.; Sharff, A.; Vonrhein, C.; Bricogne, G., Starasino. 2017.

24. Vagin, A.; Teplyakov, A., MOLREP: an automated program for molecular replacement. $J$. Appl. Cryst. 1997, 30, 1022-1025.

25. Adams, P. D.; Afonine, P. V.; Bunkoczi, G.; Chen, V. B.; Davis, I. W.; Echols, N.; Headd, J. J.; Hung, L. W.; Kapral, G. J.; Grosse-Kunstleve, R. W.; McCoy, A. J.; Moriarty, N. W.; Oeffner, R.; Read, R. J.; Richardson, D. C.; Richardson, J. S.; Terwilliger, T. C.; Zwart, P. H., PHENIX: a comprehensive Python-based system for macromolecular structure solution. Acta Cryst. 2010, D66, 213-221.

26. Winn, M. D.; Ballard, C. C.; Cowtan, K. D.; Dodson, E. J.; Emsley, P.; Evans, P. R.; Keegan, R. M.; Krissinel, E. B.; Leslie, A. G. W.; McCoy, A.; McNicholas, S. J.; Murshudov, G. N.; Pannu, N. S.; Potterton, E. A.; Powell, H. R.; Read, R. J.; Vagin, A.; Wilson, K. S., Overview of the CCP4 suite and current developments. Acta. Cryst. 2011, D67, 235-242. 
27. Marceau, A. H.; Bahng, S.; Massoni, S. C.; George, N. P.; Sandler, S. J.; Marians, K. J.; Keck, J. L., Structure of the SSB-DNA polymerase III interface and its role in DNA replication. Embo J 2011, 30, (20), 4236-4247.

28. Phillips, J.; Braun, R.; Wang, W.; Gumbart, J.; Tajkhorshid, E.; Villa, E.; Chipot, C.; Skeel, R. D.; Kalé, L.; Schulten, K., Scalable molecular dynamics with NAMD. Journal of Computationnal Chemistry 2005, 26, (16), 1781-1802.

29. Beveridge, D. L.; DiCapua, F. M., Free energy via molecular simulation: applications to chemical and biomolecular systems. Annu Rev Biophys Biophys Chem 1989, 18, 431-492.

30. Pohorille, A.; Jarzynski, C.; Chipot, C., Good practices in free-energy calculations. J Phys Chem B 2010, 114, (32), 10235-10253.

31. MacKerell, A. D.; Bashford, D.; Bellott, M.; Dunbrack, R. L.; Evanseck, J. D.; Field, M. J.; Fischer, S.; Gao, J.; Guo, H.; Ha, S.; Joseph-McCarthy, D.; Kuchnir, L.; Kuczera, K.; Lau, F. T. K.; Mattos, C.; Michnick, S.; Ngo, T.; Nguyen, D. T.; Prodhom, B.; Reiher, W. E.; Roux, B.; Schlenkrich, M.; Smith, J. C.; Stote, R.; Straub, J.; Watanabe, M.; Wiorkiewicz-Kuczera, J.; Yin, D.; Karplus, M., All-atom empirical potential for molecular modeling and dynamics studies of proteins. J Phys Chem B 1998, 102, 3586-3616.

32. Dumas, P.; Ennifar, E.; Da Veiga, C.; Bec, G.; Palau, W.; Di Primo, C.; Pineiro, A.; Sabin, J.; Munoz, E.; Rial, J., Joining Thermodynamics and kinetics by kinITC. In Methods in Enzymology. Biocalorimetry. Foundations and contemporary approaches, Feig, A. L., Ed. CRC Press: 2016; Vol. 567, pp 281-300.

33. Spolar, R. S.; Record, M. T., Jr., Coupling of local folding to site-specific binding of proteins to DNA. Science 1994, 263, (5148), 777-784.

34. Livingstone, J. R.; Spolar, R. S.; Record, M. T., Jr., Contribution to the thermodynamics of protein folding from the reduction in water-accessible nonpolar surface area. Biochemistry 1991, 30, (17), 4237-4244.

35. Connelly, P. R.; Thomson, J. A., Heat capacity changes and hydrophobic interactions in the binding of FK506 and rapamycin to the FK506 binding protein. Proc Natl Acad Sci U S A 1992, 89, (11), 4781-4785.

36. Dohrmann, P. R.; McHenry, C. S., A bipartite polymerase-processivity factor interaction: only the internal beta binding site of the alpha subunit is required for processive replication by the DNA polymerase III holoenzyme. J Mol Biol 2005, 350, (2), 228-239.

37. Bruck, I.; O'Donnell, M., The DNA replication machine of a gram-positive organism. J Biol Chem 2000, 275, (37), 28971-28983. 
TOC

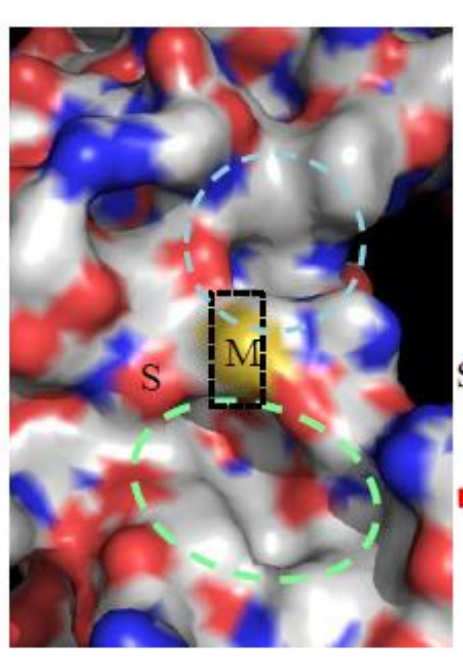

E. Coli wild type

B. Subtilis wild type
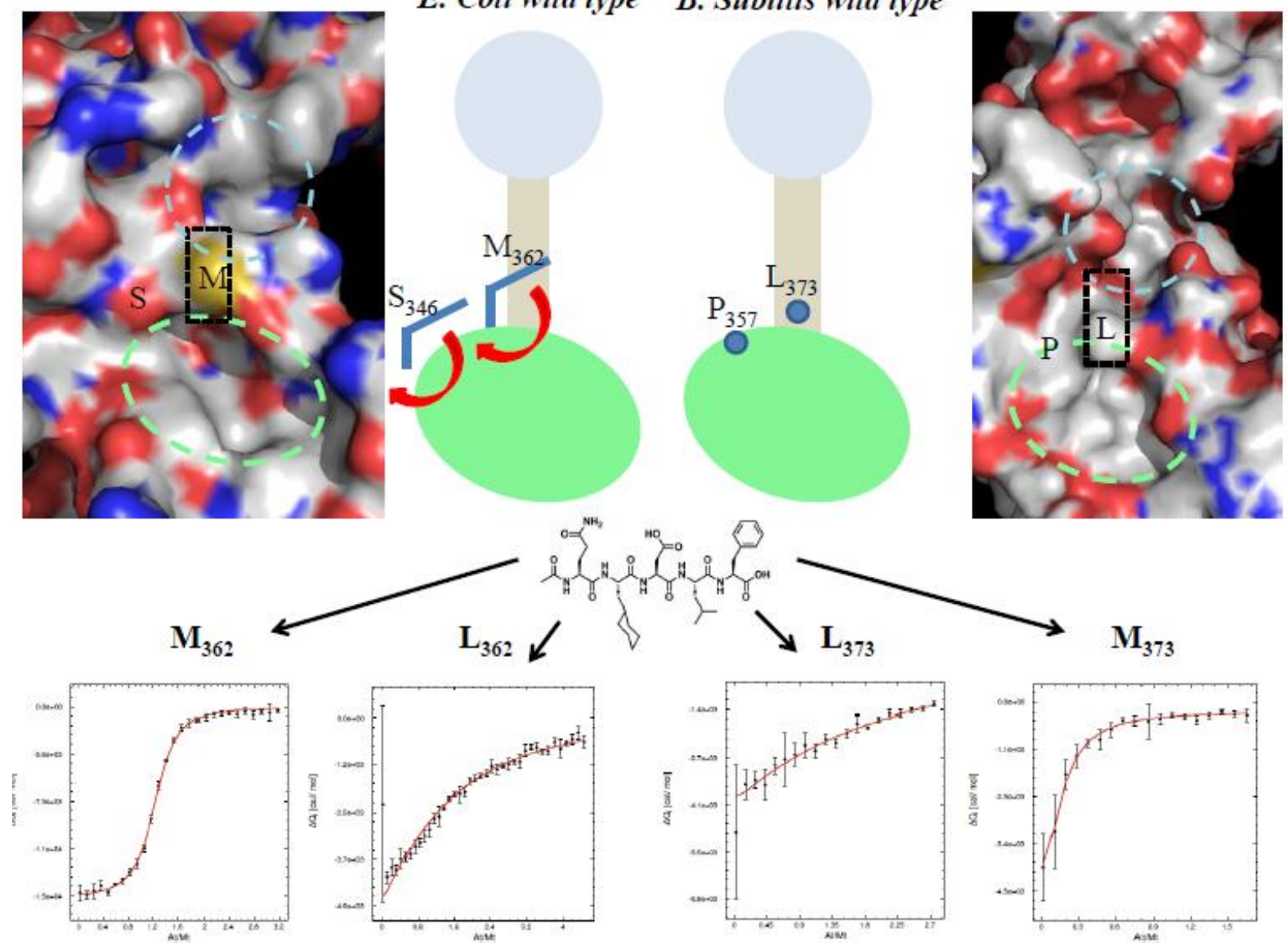

in
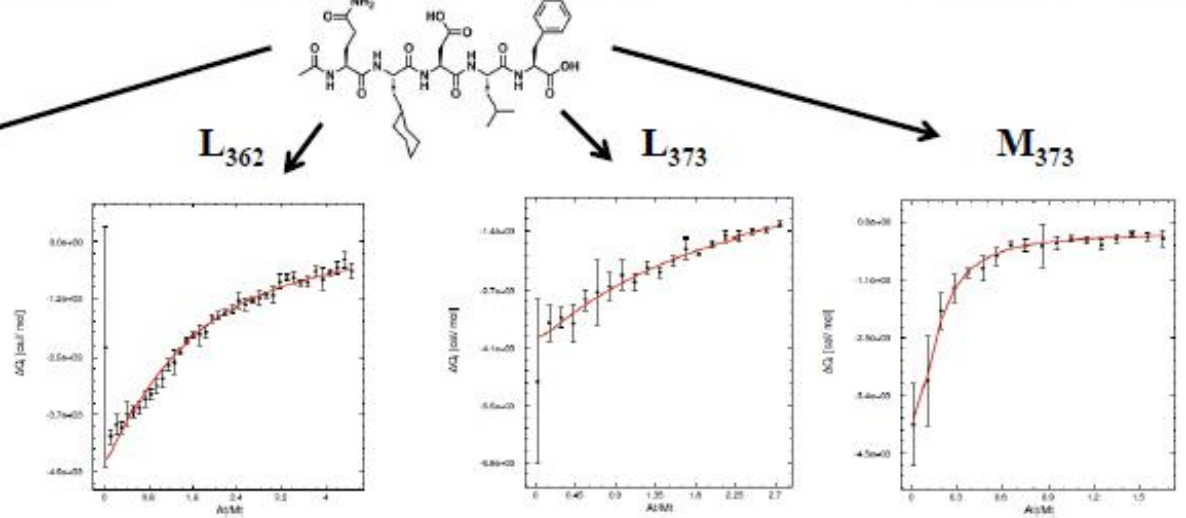